\title{
Recent satellite-based trends of tropospheric nitrogen dioxide over large urban agglomerations worldwide
}

\author{
P. Schneider ${ }^{1}$, W. A. Lahoz $^{1}$, and R. van der $A^{2}$ \\ ${ }^{1}$ NILU - Norwegian Institute for Air Research, P.O. Box 100, 2027 Kjeller, Norway \\ ${ }^{2}$ Royal Netherlands Meteorological Institute (KNMI), P.O. Box 201, 3730 AE De Bilt, the Netherlands \\ Correspondence to: P. Schneider (ps@nilu.no)
}

Received: 2 July 2014 - Published in Atmos. Chem. Phys. Discuss.: 19 September 2014

Revised: 21 December 2014 - Accepted: 6 January 2015 - Published: 3 February 2015

\begin{abstract}
Trends in tropospheric nitrogen dioxide $\left(\mathrm{NO}_{2}\right)$ columns over 66 large urban agglomerations worldwide have been computed using data from the SCanning Imaging Absorption spectroMeter for Atmospheric CHartographY (SCIAMACHY) instrument onboard the Envisat platform for the period August 2002 to March 2012. A seasonal model including a linear trend was fitted to the satellite-based time series over each site. The results indicate distinct spatial patterns in trends. While agglomerations in Europe, North America, and some locations in East Asia/Oceania show decreasing tropospheric $\mathrm{NO}_{2}$ levels on the order of $-5 \% \mathrm{yr}^{-1}$, rapidly increasing levels of tropospheric $\mathrm{NO}_{2}$ are found for agglomerations in large parts of Asia, Africa, and South America. The site with the most rapidly increasing absolute levels of tropospheric $\mathrm{NO}_{2}$ was found to be Tianjin in China with a trend of $3.04( \pm 0.47) \times 10^{15}$ molecules $\mathrm{cm}^{-2} \mathrm{yr}^{-1}$, whereas the site with the most rapidly increasing relative trend was Kabul in Afghanistan with 14.3 $( \pm 2.2) \% \mathrm{yr}^{-1}$. In total, 34 sites exhibited increasing trends of tropospheric $\mathrm{NO}_{2}$ throughout the study period, 24 of which were found to be statistically significant. A total of 32 sites showed decreasing levels of tropospheric $\mathrm{NO}_{2}$ during the study period, of which 20 sites did so at statistically significant magnitudes. Overall, going beyond the relatively small set of megacities investigated previously, this study provides the first consistent analysis of recent changes in tropospheric $\mathrm{NO}_{2}$ levels over most large urban agglomerations worldwide, and indicates that changes in urban $\mathrm{NO}_{2}$ levels are subject to substantial regional differences as well as influenced by economic and demographic factors.
\end{abstract}

\section{Introduction}

More than half of the world's population now lives in urban areas. Megacities, i.e., cities with more than 10 million inhabitants, as well as other large urban agglomerations have seen rapid growth over the last decades and this trend is expected to continue in the near future (United Nations, 2012a). The number of megacities is expected to rise from currently 23 to a total of 37 megacities in the year 2025 (Zhu et al., 2012). Such large urban agglomerations exhibit intensive human activities and high levels of energy consumption. This leads to very high emissions of a wide variety of air pollutants and greenhouse gases, severely affecting both air quality and climate (Mage et al., 1996; Mayer, 1999; Fenger, 1999; Molina and Molina, 2004; Molina et al., 2004; Gurjar et al., 2008; Chan and Yao, 2008; Monks et al., 2009; Gurjar et al., 2010; Baklanov et al., 2010; Parrish et al., 2011; Kanakidou et al., 2011; Cassiani et al., 2013).

Nitrogen dioxide $\left(\mathrm{NO}_{2}\right)$ is one of the major air pollutants and is strongly related to population density (Lamsal et al., 2013). As such it is a significant environmental issue in many large urban agglomerations (Schneider and van der A, 2012; Liu and Zhu, 2013; Hilboll et al., 2013; Guerreiro et al., 2014). $\mathrm{NO}_{2}$, which is primarily emitted by transportation, industry, and domestic heating, is associated with health issues such as airway inflammation and reductions in lung function (World Health Organization, 2013). However, station observations of $\mathrm{NO}_{2}$ are relatively rare on a global scale, and in particular in developing countries, and thus are not able to provide a global and spatially continuous perspective. Even in areas with relatively large numbers of air quality monitoring stations such as in Europe and the United States, the sta- 
tion density is often quite low. Satellite observations on the other hand offer a unique opportunity for studying the continuous spatial patterns and the temporal dynamics of the constituents affecting air quality in general (Martin, 2008; Burrows et al., 2011; Lahoz et al., 2012; Duncan et al., 2014) and of tropospheric $\mathrm{NO}_{2}$ in particular (Richter et al., 2005; Martin, 2008; van der A et al., 2008; Zhou et al., 2012; Castellanos and Boersma, 2012; Schneider and van der A, 2012; Hilboll et al., 2013; Curier et al., 2014).

Furthermore, satellite observations of atmospheric composition are a very important part of operational chemical weather forecasting as it is for example carried out by the Copernicus Atmosphere Monitoring Service (http: //atmosphere.copernicus.eu/), which uses data assimilation techniques (Lahoz and Schneider, 2014) to make the best use of the satellite information of atmospheric composition (Flemming et al., 2009; Inness et al., 2013). The Copernicus Atmosphere Monitoring Service is being developed within the framework of a series of EU-funded research projects, the latest of them being the Monitoring Atmospheric Composition and Climate - Interim Implementation (MACC-II). Within the MACC-II project, a subproject on input data (OBS) organizes, structures, and evaluates input data related to the Copernicus Programme.

As part of this work, the feasibility of using SCanning Imaging Absorption spectroMeter for Atmospheric CartograpHY (SCIAMACHY) data for estimating trends in tropospheric $\mathrm{NO}_{2}$ was investigated and is reported on here. While SCIAMACHY is not operational anymore and thus does not contribute to the Copernicus Atmosphere Monitoring Service at this point, other existing instruments such as the Global Ozone Monitoring Experiment-2 (GOME-2) (Callies et al., 2000) and the Ozone Monitoring Instrument (OMI) (Levelt et al., 2006) do so, and the presented methodology can be readily linked to these. Furthermore, future Copernicus satellites such as Sentinel-5p, Sentinel-5, and later on the geostationary Sentinel-4 will carry on the existing $\mathrm{NO}_{2}$ record provided by SCIAMACHY and other instruments. It is therefore important to discuss the methodology and results obtained for a predecessor instrument, as they will be just as applicable and relevant for the successor instruments funded within the framework of the Copernicus programme. Furthermore, there is a strong link between trends in satellitebased $\mathrm{NO}_{2}$ columns and changes in nitrogen oxide $\left(\mathrm{NO}_{\mathrm{x}}\right)$ emissions, which in turn have an important effect on the quality of the results provided by modeling systems for atmospheric composition such as the Copernicus Atmospheric Monitoring Service.

Going beyond trends determined over actual megacities as done in previous studies (Schneider and van der A, 2012; Hilboll et al., 2013), we present here the first detailed satellite-based global analysis of tropospheric $\mathrm{NO}_{2}$ trends for a significantly expanded set of of large urban agglomerations worldwide. The trends are derived from a consistent and homogeneous satellite time series for the period from August
2002 through March 2012, making use of the full archive of SCIAMACHY data.

The manuscript is structured as follows: Section 2 summarizes the current state of knowledge with respect to global and regional satellite-based $\mathrm{NO}_{2}$ trend analysis. Section 3 describes the data sets used in this study and introduces the methodology applied for calculating the trends. Section 4 subsequently presents the results, including a full overview of the derived trends and statistics for all sites, a discussion of large-scale spatial patterns in trends, an analysis of a global average time series, a discussion of the impact of the time series extraction methodology, and finally a discussion of the relationship between $\mathrm{NO}_{2}$ trends and population growth. Section 5 provides a summary and conclusions.

\section{Background}

Spaceborne observations of $\mathrm{NO}_{2}$ have been carried out since 1995 when the Global Ozone Monitoring Experiment (GOME) instrument was launched on the European ERS-2 platform. Since then, several studies have investigated temporal trends in tropospheric $\mathrm{NO}_{2}$ provided by spaceborne platforms. Richter et al. (2005) were the first to study spacebased $\mathrm{NO}_{2}$ trends and provided a trend analysis based primarily on GOME $\mathrm{NO}_{2}$ data over China. Later on, van der A et al. (2006) and van der A et al. (2008) combined data from the GOME and the SCIAMACHY instrument and provided a trend analysis focused on China and over the entire globe, respectively. A combination of GOME and SCIAMACHY data was also used by Ghude et al. (2009) for studying regional trends in tropospheric $\mathrm{NO}_{2}$. Using a similar methodology, $\mathrm{NO}_{2}$ trends over emission hotspots in India were further studied by Ghude et al. (2008). Hayn et al. (2009) used generalized additive models to study spatiotemporal patterns in tropospheric $\mathrm{NO}_{2}$ columns derived from GOME data between 1996 and 2001. Summertime trends in European $\mathrm{NO}_{\mathrm{x}}$ emissions were studied by Konovalov et al. (2008) using a combination of GOME, SCIAMACHY, and a continentalscale air quality model. The methodology was later extended to study non-linear $\mathrm{NO}_{2}$ and $\mathrm{NO}_{\mathrm{x}}$ trends for several urban agglomerations in Europe and Asia, using a method based on a probabilistic approach and artificial neural networks (Konovalov et al., 2010). The same combination of satellite instruments was further used by Kim et al. (2006) to quantify decreases in $\mathrm{NO}_{\mathrm{x}}$ emissions over US power plants. Russell et al. (2012) studied the effect of emission control measures and the impact of the economic recession in the United States using OMI data. De Ruyter de Wildt et al. (2012) further investigated trends of tropospheric $\mathrm{NO}_{2}$ over some of the major shipping lanes in the world. Studies focusing on changes in tropospheric $\mathrm{NO}_{2}$ levels over individual megacities have also been carried out. For example, using data from multiple satellite instruments, Vrekoussis et al. (2013) studied the impact of the economic crisis on the megacity of 
Athens, Greece. Furthermore, Sitnov (2011) studied OMIbased $\mathrm{NO}_{2}$ column trends between 2004 and 2009 over the megacity of Moscow, Russia. Constantin et al. (2013) studied time series of tropospheric $\mathrm{NO}_{2}$ from multiple satellite instruments over several locations in Romania. Ionov (2010) investigated the trend in tropospheric $\mathrm{NO}_{2}$ column over St. Petersburg, Russia, using a combination of GOME, SCIAMACHY, and OMI data and found a linear increase of approximately $4 \%$ per year. SCIAMACHY-based $\mathrm{NO}_{2}$ column trends over four large urban agglomerations in India for the period 2004 through 2010 have further been studied by Meena et al. (2012).

In recent years, spatial patterns and temporal changes in tropospheric $\mathrm{NO}_{2}$ columns over Europe have been studied in great detail. Based on the work by Hayn et al. (2009), Zhou et al. (2012) used a generalized additive model together with $6 \mathrm{yr}$ of OMI data to study factors influencing the variability of $\mathrm{NO}_{2}$ columns. They found consistent and significant negative trends mostly in areas of anthropogenic sources over Western Europe and isolated and scattered positive trends in Eastern Europe, which is in agreement with many other studies, such as for example, Schneider and van der A (2012). Castellanos and Boersma (2012) studied the changes in OMI-based $\mathrm{NO}_{2}$ columns between 2004 and 2010 over Europe. They found substantial reductions in $\mathrm{NO}_{2}$ in many parts of Europe, which they attribute in part to European $\mathrm{NO}_{\mathrm{x}}$ emission controls and in part to temporary emissions reductions due to the 20082009 global economic recession. Using OMI-derived tropospheric columns for $\mathrm{NO}_{2}$ in conjunction with the chemistry transport model LOTOS-EUROS, Curier et al. (2014) studied trends in $\mathrm{NO}_{\mathrm{x}}$ emissions over Europe. Similarly to other studies they found significant negative trends of $5-6 \% \mathrm{yr}^{-1}$ in highly industrialized regions of Europe, with the strongest reductions in northern Spain and the Po Valley.

Schneider and van der A (2012) made use of a homogeneous 9 yr time series acquired by the SCIAMACHY instrument and provided the first single-sensor global trend analysis of $\mathrm{NO}_{2}$, thus avoiding the merging of data sets with substantially different spatial resolution and possible intersensor calibration issues. They further analyzed trends over some of the major megacities but did not provide much detail on this issue. For this study we follow the approach suggested by Schneider and van der A (2012) and use data from the SCIAMACHY instrument. However in contrast to Schneider and van der A (2012) we use the full SCIAMACHY archive and an improved version of the satellite data product. The chosen approach has the advantage of providing very homogeneous time series and therefore highly reliable trends. Combining data from multiple instruments generally requires either resampling to a coarser-resolution grid in order to eliminate the impact of different spatial resolutions (van der A et al., 2006, 2008) or involves schemes for homogenizing the data sets using resolution correction factors (Konovalov et al., 2006; Hilboll et al., 2013) or empirical statistical approaches taking into account level-shift
(Mieruch et al., 2008; Hilboll et al., 2013). Although significant progress has been made in techniques on combining data from multiple instruments (Hilboll et al., 2013), computing trends from homogeneous time series based on a single instrument still has the advantage that the computed trends are very likely to be real geophysical trends and are guaranteed not to be affected by different characteristics between instruments.

\section{Data and methodology}

The data and methodology used here are largely consistent with those used previously in Schneider and van der A (2012). However, there are a few important novel aspects to this work: (a) the primary focus of the study lies on large urban agglomerations (b) the length of the time series has now been expanded to include the entire available archive of SCIAMACHY data ranging from August 2002 to March 2012 (c) a new and improved version of the $\mathrm{NO}_{2}$ retrieval algorithm (v2.3) (Boersma et al., 2004) has been used, and (d) compared to previous studies the list of large urban agglomerations has been significantly expanded and the resulting trends are studied in more detail.

\subsection{Satellite data}

Data from the SCIAMACHY instrument onboard the European Space Agency's Envisat platform was used in this study as it provides a homogeneous $10 \mathrm{yr}$ time series of global tropospheric $\mathrm{NO}_{2}$ observations (Bovensmann et al., 1999; Gottwald et al., 2011). SCIAMACHY is a hyperspectral UV/VIS/NIR passive grating spectrometer observing the wavelength range of $214-2386 \mathrm{~nm}$. The entire archive of SCIAMACHY $\mathrm{NO}_{2}$ data was used (see Fig. 1). The record starts in August 2002 and ends in early April 2012 due to the loss of communication with the Envisat platform. The SCIAMACHY data product of monthly mean tropospheric $\mathrm{NO}_{2}$ that was used here was processed using a combined retrieval/assimilation approach (Boersma et al., 2004; Dirksen et al., 2011) and acquired from the website of the Tropospheric Emission Monitoring Internet Service (TEMIS) (http://temis.nl/). The original satellite retrievals are regridded on a regular 0.25 degree $\times 0.25$ degree grid by averaging the satellite observations weighted by the size of the overlapping surface area.

The product is derived in a three step approach consisting of (a) differential optical absorption spectroscopy (DOAS) retrieval of the slant column, (b) a separation of the tropospheric and stratospheric contribution (Dirksen et al., 2011) based on the TM4 chemical transport model (Dentener et al., 2003; Boersma et al., 2007), and (c) the conversion of the slant column densities (SCDs) into vertical column densities (VCDs) using a calculated air mass factor (AMF). While the retrieval in general considers all cloud radiance fractions, the 


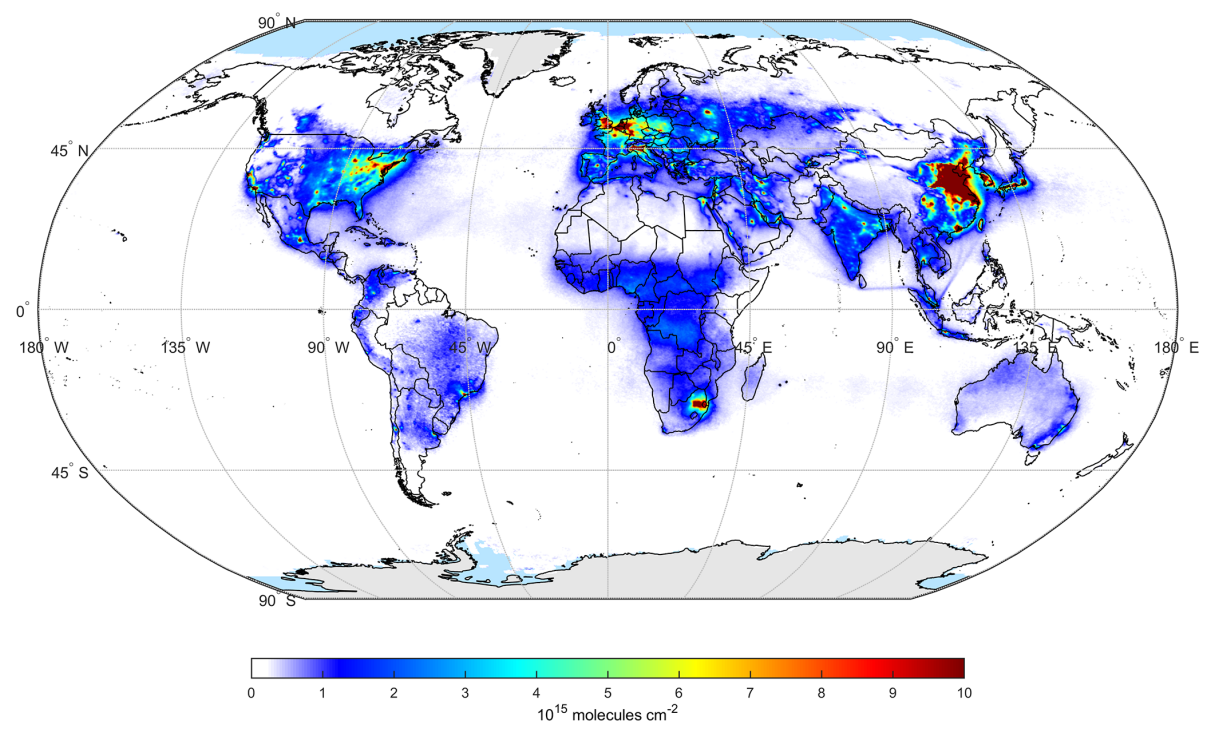

Figure 1. Global map of long-term average tropospheric $\mathrm{NO}_{2}$ column derived from SCIAMACHY data (given in units of $\times 10^{15}$ molecules $\mathrm{cm}^{-2}$ ). The average was computed over the entire time series of SCIAMACHY data ranging from August 2002 to March 2012. The faint linear feature in the North Atlantic is not a real signal but an artefact of the retrieval process. It does not affect the analysis of trends in urban agglomerations presented here.

monthly means are calculated only from data with cloud radiance fractions of less than $50 \%$. The $\mathrm{NO}_{2}$ product is provided on a global grid of 0.25 degree by 0.25 degree spatial resolution. Version 2.3 of the product was used here. In addition to the major improvements to the retrieval algorithm introduced with version 2.0 (Boersma et al. (2011), and summarized in Schneider and van der A, 2012), version 2.3 further improved the algorithm by correcting some minor retrieval errors. Further details on the specific retrieval methodology can be found in Boersma et al. (2004), Boersma et al. (2007), and Boersma et al. (2011), as well as on the TEMIS website.

$\mathrm{NO}_{2}$ retrievals from SCIAMACHY have been validated in numerous studies, e.g., by Heue et al. (2005) using airborne multi-axis differential optical absorption spectroscopy observations, by Boersma et al. (2009) using in situ surface observations in Israel, and by Irie et al. (2012) using inter-comparison techniques with $\mathrm{NO}_{2}$ products derived from other satellite instruments as well as multi-axis differential optical absorption spectroscopy (MAX-DOAS) observations in Japan and China. The last one showed that SCIAMACHY-based tropospheric $\mathrm{NO}_{2}$ columns were accurate with a $-5 \%$ bias and standard deviation of $\pm 14 \%$. The impact of topography on SCIAMACHY $\mathrm{NO}_{2}$ retrievals was investigated by Schaub et al. (2007) who found errors of up to $40 \%$ over very complex terrain. Blond et al. (2007) intercompared SCIAMACHY-based $\mathrm{NO}_{2}$ retrievals with in situ station observations over Europe and found biases of less than $5 \%$ and $20 \%$ for annual and seasonal averages, respectively.

\subsection{Site selection}

The large urban agglomerations studied here were selected primarily based on population size as given by United Nations (2012b). All "true" megacities, i.e., cities with a population of greater than 10 million inhabitants, were included. In addition, most urban agglomerations with a population of more than 5 million as well as some special-interest sites with slightly less than 5 million inhabitants were also considered. Such special-interest sites were defined on a case by case basis primarily based on properties such as rapid population growth and/or known air quality issues, characteristics as a hotspot in an otherwise unpolluted region, or in order to obtain a reasonably balanced distribution of study sites over the globe.

Overall, 66 large urban agglomerations were identified for the analysis. Of those, 7 were located in Africa, 15 in East Asia, 7 in Europe, 10 in North America, 2 in Oceania, 6 in South America, 9 in South Asia, 4 in Southeast Asia, and 5 in West Asia. A full list of the studied sites including additional information about their location and their estimated population is given in Table 1 .

\subsection{Trend analysis}

At each of the sites identified based on the methodology described in Sect. 3.2, time series of mean monthly tropospheric $\mathrm{NO}_{2}$ were extracted from the full SCIAMACHY archive between August 2002 and March 2012. Subsequently a statistical model was fitted to the time series over each site. The monthly average $\mathrm{NO}_{2}$ tropospheric column $C_{t}$ at 
Table 1. Metadata of the selected megacities and other large urban agglomerations. A total of 66 sites were selected based on the criteria listed in Sect. 3.2. The given latitude and longitude values indicate the location at which the time series was extracted from the SCIAMACHY data set. The data on estimated population was taken from United Nations (2012b).

\begin{tabular}{|c|c|c|c|c|}
\hline City name & Country & Lat. $\left[{ }^{\circ} \mathrm{N}\right]$ & Lon. $\left[{ }^{\circ} \mathrm{E}\right]$ & Pop. [mill.] \\
\hline Algiers & Algeria & 36.76 & 3.04 & 3.4 \\
\hline Athens & Greece & 37.98 & 23.73 & 3.6 \\
\hline Atlanta & USA & 33.76 & -84.39 & 5.4 \\
\hline Baghdad & Iraq & 33.32 & 44.40 & 6.4 \\
\hline Bangalore & India & 12.97 & 77.60 & 9.5 \\
\hline Bangkok & Thailand & 13.72 & 100.54 & 14.3 \\
\hline Beijing & China & 39.91 & 116.37 & 16.9 \\
\hline Bogota & Colombia & 4.65 & -74.10 & 9.2 \\
\hline Boston & USA & 42.37 & -71.07 & 7.2 \\
\hline Buenos Aires & Argentina & -34.62 & -58.46 & 14.5 \\
\hline Cairo & Egypt & 30.04 & 31.24 & 16.0 \\
\hline Chengdu & China & 30.66 & 104.06 & 6.4 \\
\hline Chicago & USA & 41.88 & -87.67 & 9.8 \\
\hline Chongqing & China & 29.56 & 106.55 & 6.4 \\
\hline Damascus & Syria & 33.51 & 36.30 & 3.5 \\
\hline Delhi & India & 28.63 & 77.22 & 23.7 \\
\hline Dhaka & Bangladesh & 23.74 & 90.40 & 16.0 \\
\hline Guangzhou & China & 23.13 & 113.24 & 26.4 \\
\hline Ho Chi Minh City & Vietnam & 10.78 & 106.66 & 8.1 \\
\hline Hong Kong & China & 22.32 & 114.18 & 7.2 \\
\hline Houston & USA & 29.76 & -95.37 & 5.9 \\
\hline Hyderabad & India & 17.39 & 78.48 & 8.5 \\
\hline Istanbul & Turkey & 41.01 & 28.97 & 13.6 \\
\hline Jakarta & Indonesia & -6.22 & 106.85 & 26.0 \\
\hline Jeddah & Saudi Arabia & 21.53 & 39.20 & 3.9 \\
\hline Johannesburg & South Africa & -26.20 & 28.04 & 8.5 \\
\hline Kabul & Afghanistan & 34.53 & 69.17 & 3.5 \\
\hline Karachi & Pakistan & 24.88 & 67.04 & 22.3 \\
\hline Khartoum & Sudan & 15.55 & 32.53 & 5.2 \\
\hline Kinshasa & Congo & -4.34 & 15.31 & 9.8 \\
\hline Kolkata & India & 22.57 & 88.36 & 15.9 \\
\hline Lagos & Nigeria & 6.51 & 3.35 & 13.0 \\
\hline Lahore & Pakistan & 31.51 & 74.34 & 9.4 \\
\hline Lima & Peru & -12.05 & -77.04 & 9.6 \\
\hline London & Great Britain & 51.51 & -0.11 & 13.3 \\
\hline Los Angeles & USA & 33.92 & -118.08 & 17.1 \\
\hline Madras & India & 13.07 & 80.22 & 9.5 \\
\hline Manila & Philippines & 14.61 & 121.02 & 21.9 \\
\hline Melbourne & Australia & -37.80 & 145.05 & 4.2 \\
\hline Mexico City & Mexico & 19.42 & -99.13 & 23.6 \\
\hline Moscow & Russia & 55.75 & 37.62 & 16.3 \\
\hline Mumbai & India & 19.08 & 72.88 & 21.2 \\
\hline Nagoya & Japan & 35.19 & 136.85 & 8.5 \\
\hline Nairobi & Kenya & -1.29 & 36.83 & 4.7 \\
\hline New York & USA & 40.76 & -73.97 & 21.6 \\
\hline Osaka & Japan & 34.65 & 135.51 & 16.8 \\
\hline Paris & France & 48.86 & 2.35 & 10.6 \\
\hline Philadelphia & USA & 39.96 & -75.16 & 7.3 \\
\hline Po Valley & Italy & 45.47 & 9.19 & 24.3 \\
\hline Rhein-Ruhr & Germany & 51.49 & 7.08 & 4.6 \\
\hline Rio de Janeiro & Brazil & -22.85 & -43.32 & 12.8 \\
\hline Riyadh & Saudi Arabia & 24.69 & 46.73 & 6.1 \\
\hline San Francisco & USA & 37.75 & -122.43 & 7.2 \\
\hline Santiago & Chile & -33.46 & -70.64 & 6.3 \\
\hline Sao Paulo & Brazil & -23.55 & -46.64 & 21.4 \\
\hline Seoul & Korea (South) & 37.54 & 126.97 & 25.6 \\
\hline Shanghai & China & 31.23 & 121.48 & 26.0 \\
\hline Shenyang & China & 41.81 & 123.43 & 7.3 \\
\hline Shenzhen & China & 22.58 & 114.05 & 10.1 \\
\hline Sydney & Australia & -33.91 & 151.06 & 4.7 \\
\hline Taipei & Taiwan & 25.04 & 121.51 & 9.0 \\
\hline Tehran & Iran & 35.70 & 51.41 & 13.8 \\
\hline Tianjin & China & 39.14 & 117.20 & 10.1 \\
\hline Tokyo & Japan & 35.70 & 139.76 & 34.7 \\
\hline Washington & USA & 38.90 & -77.02 & 8.1 \\
\hline Wuhan & China & 30.56 & 114.32 & 9.3 \\
\hline
\end{tabular}

time $t$ (in months) was modeled following Weatherhead et al. (1998) and Schneider and van der A (2012) as

$C_{t}=\mu+S_{t}+\frac{1}{12} \omega t+R_{t}$,

where $\mu$ is a constant, $S_{t}$ is a seasonal component, which is a assumed to be constant in time, $\omega$ is a linear trend and $R_{t}$ is the residual variability. The seasonal component $S_{t}$ is modeled as

$S_{t}=\sum_{j=1}^{4}\left[\beta_{1, j} \sin \left(\frac{2 \pi j t}{12}\right)+\beta_{2, j} \cos \left(\frac{2 \pi j t}{12}\right)\right]$,

where $\beta_{1,1}$ through $\beta_{2,4}$ are coefficients of the fit. The residual variability $R_{t}$ is assumed to be autoregressive of order 1 and was modeled as

$R_{t}=\phi R_{t-1}+\epsilon_{t}$,

where $\phi$ is the first order autocorrelation, and $\epsilon$ is a random error component.

Based on the work by Tiao et al. (1990) and Weatherhead et al. (1998) and following the methodology described in Schneider and van der A (2012), the significance of the trend was calculated such that the trend $\omega$ is considered as significant with a $95 \%$ confidence if

$\left|\omega / \sigma_{\omega}\right|>t_{\omega}$,

where $\sigma_{\omega}$ is the uncertainty of the trend and $t_{\omega}$ is the value of the Student's $t$ distribution for a significance level of $\alpha=$ 0.05 and the degrees of freedom given for the time series (Santer et al., 2000).

The trend uncertainty $\sigma_{\omega}$ is computed following Weatherhead et al. (1998) and Schneider and van der A (2012) as

$\sigma_{\omega}=\left[\frac{\sigma_{r}}{n^{3 / 2}} \sqrt{\frac{1+\phi}{1-\phi}}\right]$,

where $\sigma_{r}$ is the standard deviation of the de-trended residuals, $n$ is the number of years with available data, and $\phi$ is the first-order autocorrelation.

Relative trends $\omega_{\text {rel }}$ given in $\%$ per year are computed from the absolute trends $\omega_{\text {abs }}$ given in units of molecules $\mathrm{cm}^{-2} \mathrm{yr}^{-1}$ with respect to the long-term average tropospheric $\mathrm{NO}_{2}$ column $\overline{\mathrm{VCD}}$ trop (see Fig. 1) as calculated over the original time series at each grid cell. The relative trend $\omega_{\text {rel }}$ is then calculated at each individual grid cell as

$\omega_{\text {rel }}=\frac{\omega_{\text {abs }}}{\overline{\mathrm{VCD}}_{\text {trop }}} \cdot 100$.

This approach of calculating the relative magnitude of the $\mathrm{NO}_{2}$ trends differs from those taken by previous studies (e.g., van der A et al., 2006, 2008; Hilboll et al., 2013) in that it does not use a single reference year at the beginning of the 


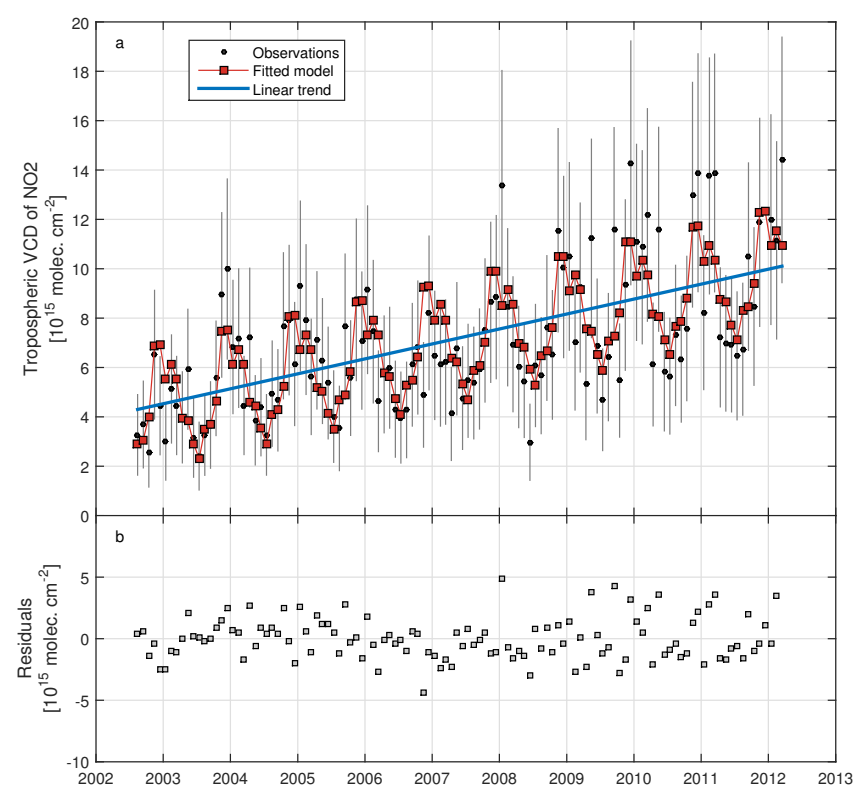

Figure 2. Example of a SCIAMACHY-derived time series of monthly mean tropospheric $\mathrm{NO}_{2}$ column (given in units of $\times 10^{15}$ molecules $\mathrm{cm}^{-2}$ ) including estimated uncertainty for the city of Baghdad, Iraq and the fitted statistical model including linear trend (top) and the corresponding residuals of the fitted model (bottom) (given in units of $\times 10^{15}$ molecules $\mathrm{cm}^{-2}$ ).

time series and thus is less sensitive to potential outliers at the grid-cell level for the reference year. However, it should be noted that the relative trends reported in this study are therefore not directly comparable to previous studies as they generally show values of lower magnitude.

Figure 2a shows an example of the SCIAMACHY-derived time series of monthly mean tropospheric $\mathrm{NO}_{2}$ columns together with the statistical model and its linear trend component, which was fitted using the methodology described in this section. In this example, which shows the evolution of the tropospheric $\mathrm{NO}_{2}$ columns over the city of Baghdad, Iraq, the absolute trend was found to be $0.6( \pm 0.08)$ $\times 10^{15}$ molecules $\mathrm{cm}^{-2} \mathrm{yr}^{-1}$ and the relative trend with respect to the long-term average tropospheric column levels of $\mathrm{NO}_{2}$ was found to be $8.5( \pm 1.2) \%$ per year. Both trends were found to be significant at a $95 \%$ confidence. Figure $2 b$ further shows the residuals of the fitted model. The residuals were found to have a mean value of $-0.0007 \times 10^{15}$ molecules $\mathrm{cm}^{-2}$ with a standard deviation of $1.7 \times 10^{15}$ molecules $\mathrm{cm}^{-2}$. The residuals were found to be normally distributed using the Jarque-Bera goodness-of-fit test (Jarque and Bera, 1987).

In general, we found that the linear trend component of the model, which is the sole purpose of performing the fit of the statistical model in this study, is quite robust even in the presence of occasionally high residuals. However, future work should consider the use of a statistical model that provides the possibility of a variable amplitude in the annual cycle as has been shown for example by Hilboll et al. (2013). Another potential option are generalized additive models as used by Hayn et al. (2009) and Zhou et al. (2012). While these methods would improve the model fit and thus lower the magnitude of the residuals, the linear trend component of the model is unlikely to be significantly affected, which is corroborated by the fact that despite differing methodologies most of the relevant studies result in overall very similar magnitudes and spatial patterns of the trends in tropospheric $\mathrm{NO}_{2}$ columns.

\subsection{Data on population growth}

Among other factors, the emissions of nitrogen oxides are generally highly dependent on population density (Lamsal et al., 2013). For this reason, the relationship between temporal changes in tropospheric $\mathrm{NO}_{2}$ and population growth of the urban agglomerations was studied. For this purpose, data on relative population growth by decade in the world's large urban agglomerations with 750000 inhabitants or more was acquired from the United Nations' World Urbanization Prospects data set (United Nations, 2012b). Data on population growth was available for the period 2000 to 2010 which agrees very closely with the study period of 2002 to 2012 used here and is thus considered to be suitable for comparison.

\section{Results and discussion}

\subsection{Global trends}

Figure 3 shows a global map of the computed trends in tropospheric $\mathrm{NO}_{2}$ over all studied large urban agglomerations. The overarching spatial patterns visible in the map indicate large-scale decreasing $\mathrm{NO}_{2}$ levels over all study sites in North America, Europe, Australia and Japan, whereas moderately to rapidly increasing trends can be observed throughout China, South Asia, as well as most of Africa and South America.

A total number of 66 large urban agglomerations were analyzed. Overall, a majority of the studied sites (44 out of 66) exhibited trends that are statistically significant at the $95 \%$ level. In total, 34 sites exhibited increasing trends of tropospheric $\mathrm{NO}_{2}$ throughout the study period, 24 of which were found to be statistically significant. A total of 32 sites showed decreasing levels of tropospheric $\mathrm{NO}_{2}$ during the study period, of which 20 sites did so at statistically significant magnitudes. It should be noted that in this study we compute trends of tropospheric $\mathrm{NO}_{2}$ columns, which differ from the actual emissions. Despite the short lifetime of $\mathrm{NO}_{\mathrm{x}}$, the $\mathrm{NO}_{2}$ concentration field develops a smooth spatial pattern roughly resembling a Gaussian distribution over the emission source, i.e., the city. However, the long-term trends will remain the same regardless of the spatial pattern in the concentration field resembling more a Gaussian or a point source. 


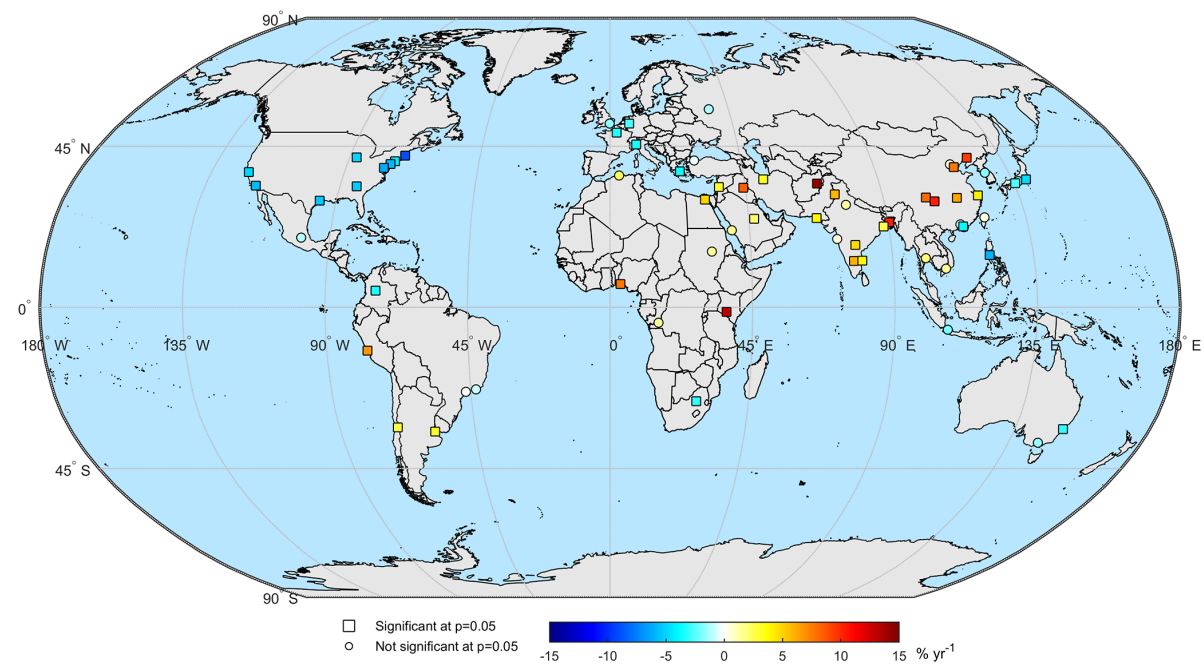

Figure 3. Global map of relative 2002-2012 tropospheric $\mathrm{NO}_{2}$ trends over all studied urban agglomerations. The relative trends in units of $\mathrm{yr}^{-1}$ are given with respect to the long-term average concentration computed over the entire time series at each grid cell individually. The names of all the studied urban agglomerations as well as the exact absolute and relative trend values for each site can be found in Table
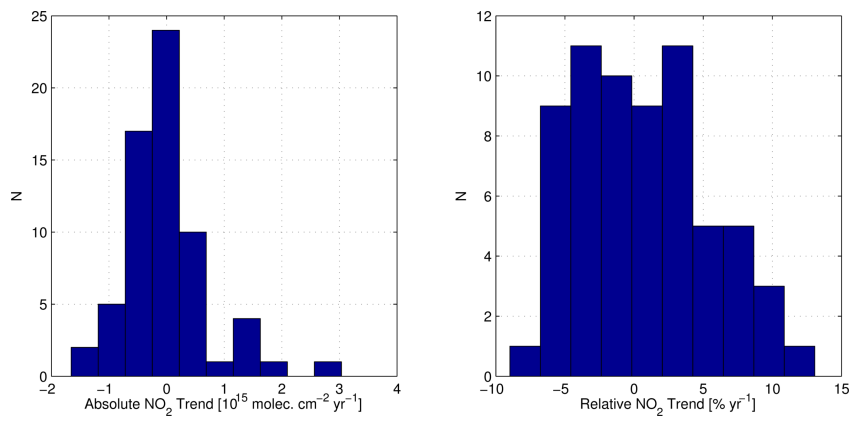

Figure 4. Histograms of absolute (left panel) and relative (right panel) tropospheric $\mathrm{NO}_{2}$ trends over large urban agglomerations worldwide. The relative trends were computed with respect to the long-term average concentration computed over the entire time series at each grid cell individually.

Figure 4 shows histograms of absolute and relative trends in tropospheric $\mathrm{NO}_{2}$ over all the large urban agglomerations studied. The majority of absolute trends falls into the range of $-1 \times 10^{15}$ molecules $\mathrm{cm}^{-2} \mathrm{yr}^{-1}$ to $0.5 \times 10^{15}$ molecules $\mathrm{cm}^{-2} \mathrm{yr}^{-1}$, but a few urban agglomerations show even more rapidly decreasing or increasing trends. Most of the relative trends fall into the range between -5 and $6 \% \mathrm{yr}^{-1}$, but several of the Asian sites exceed this range with values greater than $6 \% \mathrm{yr}^{-1}$.

The overall extreme values in trends are compiled for clarity and given in Table 2 . All of these trends are statistically significant at the $95 \%$ level. The maximum values both in absolute and relative terms were found for megacities in Asia, whereas the most rapid absolute and relative decreases were both found for cities in the United States.
It should be noted that among the "true" megacities, i.e., urban agglomerations with a population of greater than 10 million inhabitants, the city of Dhaka in Bangladesh is the site with the largest relative trend with an increase in tropospheric $\mathrm{NO}_{2}$ levels of $10.3 \% \mathrm{yr}^{-1}$ for the period studied here. This is consistent with the multi-instrument trend results reported by Hilboll et al. (2013), although the actual relative trend values differ due to the use of a different methodology for calculating the relative trends (using a single reference year in Hilboll et al. (2013) versus the long-term mean in Schneider and van der A (2012) and this study).

Table shows the absolute and relative trends derived from the entire 2002 to 2012 SCIAMACHY archive for all megacities and large urban agglomerations. For each site the estimated trend uncertainties are also included. The six sites with the most rapidly increasing tropospheric $\mathrm{NO}_{2}$ levels in absolute terms and all sites with absolute trends exceeding $1 \times 10^{15}$ molecules $\mathrm{cm}^{-2} \mathrm{yr}^{-1}$ are located in China. In addition to Kabul, three more sites exceed relative trends of $10 \% \mathrm{yr}^{-1}$, namely Nairobi, Dhaka, and Chongqing.

\subsection{Temporal analysis}

Figure 5a shows the average monthly time series computed over all study sites. While the typical seasonal cycle for $\mathrm{NO}_{2}$ can be seen in the monthly data, no clear linear trend is visible from that data. This is due to the fact that the time series represents an average over all worldwide megacities and large urban agglomerations with widely varying characteristics, including both rapidly increasing trends in Asia as well as decreasing $\mathrm{NO}_{2}$ levels in North America and Europe. Figure $5 \mathrm{a}$ also shows the fitted statistical model used to deseasonalize the time series. Figure $5 \mathrm{~b}$ shows the corresponding 
Table 2. Extreme values among the studied large urban agglomerations, both in terms of absolute and relative trends. All of the listed trends are statistically significant at the $p<0.05$ level.

\begin{tabular}{|c|c|c|}
\hline & Absolute Trends & Relative Trends \\
\hline Largest positive & $\begin{array}{c}\text { Tianjin, China } \\
2.83( \pm 0.48) \times 10^{15} \text { molecules } \mathrm{cm}^{-2} \mathrm{yr}^{-1}\end{array}$ & $\begin{array}{l}\text { Kabul, Afghanistan } \\
14.3( \pm 2.2) \% \mathrm{yr}^{-1}\end{array}$ \\
\hline Largest negative & $\begin{array}{c}\text { Los Angeles, USA } \\
-1.66( \pm 0.31) \times 10^{15} \text { molecules cm }{ }^{-2} \mathrm{yr}^{-1}\end{array}$ & $\begin{array}{c}\text { Boston, USA } \\
-9.0( \pm 3.0) \% \mathrm{yr}^{-1}\end{array}$ \\
\hline
\end{tabular}

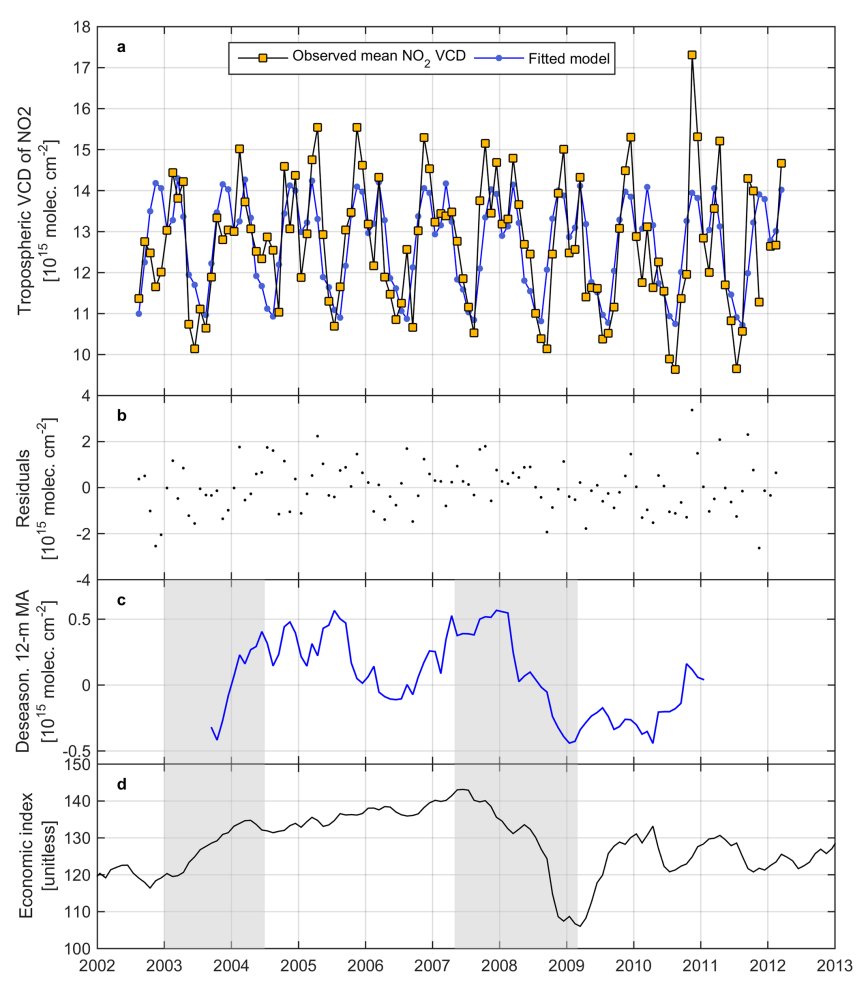

Figure 5. Average time series of SCIAMACHY-derived tropospheric $\mathrm{NO}_{2}$ column computed over all study sites including a fitted trend model (a), the model residuals (b), the 12-month moving average of the deseasonalized time series (c), and the ECRI Weekly Economic Index. Gray boxes in the two lowermost panels mark periods where the overall $\mathrm{NO}_{2}$ levels in the studied urban agglomerations appear to be indicative of overall economic activity.

residuals, which in the majority of cases have absolute values of less than $2 \times 10^{15}$ molecules $\mathrm{cm}^{-2} \mathrm{yr}^{-1}$.

To better highlight the overall signal contained in the global monthly time series, Fig. 5c further shows the 12month moving average of the deseasonalized monthly time series. The most obvious characteristic in this plot is a significant drop in tropospheric $\mathrm{NO}_{2}$ levels throughout the year 2008, which then continue at low levels throughout 2009 and 2010, after which the levels recover again slightly until 2011. This feature is most likely related to the worldwide financial crisis, which started in 2008 and had a substantial im- pact on the global economy during this period. This result provides a global perspective to supplement previous studies that looked in detail at tropospheric $\mathrm{NO}_{2}$ columns as a proxy for the economic downturn over a single megacity (Vrekoussis et al., 2013) or provided regional studies about the same topic (Russell et al., 2012; Castellanos and Boersma, 2012; De Ruyter de Wildt et al., 2012).

Figure $5 \mathrm{c}$ also indicates an increase in tropospheric $\mathrm{NO}_{2}$ levels from late 2003 through early 2004. The reason for this behavior is not as obvious. To better understand this feature, Fig. 5d shows a monthly averaged time series of the Economic Cycle Research Institute (ECRI) leading weekly economic index (https://www.businesscycle. com/ecri-reports-indexes/all-indexes). While this index is primarily intended as an indicator of the economic outlook for the United States (higher values indicate a more positive outlook), we use it here as a proxy for the global economic situation. Both the increase in 2003/2004 as well as the rapid drop in 2008 can be seen in both data sets, suggesting a link between the $\mathrm{NO}_{2}$ levels over large urban agglomerations and the economic situation. It should be noted that other features such as the small temporary decrease in $\mathrm{NO}_{2}$ levels in 2006 (Fig. 5c), or the moderate rise of the $\mathrm{NO}_{2}$ levels in 2010, are not reflected as clearly by the economic index. However, the latter could be interpreted as a slightly delayed response, keeping in mind that the $\mathrm{NO}_{2}$ levels shown in Fig. $5 c$ are global averages whereas the economic index shown in Fig. 5d is for the United States. Overall, these results indicate that the global average $\mathrm{NO}_{2}$ levels over major urban agglomerations reflect large-scale changes in the global economic situation that happen over a relatively short time-frame.

In addition to the global time series given in Fig. 5, average time series were also studied at the regional level. Figure 6 shows the interannual variability of tropospheric $\mathrm{NO}_{2}$ over all studied megacities and urban agglomerations, averaged by region. To facilitate an easier comparison between regions, the time series are given as averaged relative anomalies from the long-term mean at each site. The large-scale spatial patterns discussed previously are confirmed in this figure, with the urban agglomerations in Europe and North America exhibiting substantial decreases in $\mathrm{NO}_{2}$, and the regions of South Asia, West Asia, and Africa showing rapid increases over the only 9 yr period. North American agglomer- 
Table 3. Trend analysis results for all studied large urban agglomerations. The absolute trends and their uncertainty are given in units of $\times 10^{15}$ molecules $\mathrm{cm}^{-2} \mathrm{yr}^{-1}$ and the relative trends and their uncertainty are given in $\% \mathrm{yr}^{-1}$. The trends shown here were computed using time series extracted from a single grid cell located over the center of each agglomeration. The relative trends were computed with respect to the long term mean of the time series over a given grid cell. Trends that were found to be statistically significant at the $p<0.05$ level are marked in bold. $\mathrm{N}$ indicates the total number of months in the time series with valid data.

\begin{tabular}{|c|c|c|c|}
\hline City & $\mathrm{N}$ & Absolute Trend & Relative Trend \\
\hline Algiers & 115 & $0.096 \pm 0.066$ & $2.4 \pm 1.7$ \\
\hline Athens & 114 & $-0.213 \pm 0.081$ & $-3.6 \pm 1.4$ \\
\hline Atlanta & 108 & $-0.449 \pm 0.111$ & $-5.4 \pm 1.3$ \\
\hline Baghdad & 115 & $0.600 \pm 0.085$ & $8.5 \pm 1.2$ \\
\hline Bangalore & 87 & $0.188 \pm 0.058$ & $6.1 \pm 1.9$ \\
\hline Bangkok & 116 & $0.203 \pm 0.163$ & $1.9 \pm 1.6$ \\
\hline Beijing & 110 & $0.152 \pm 0.552$ & $0.4 \pm 1.3$ \\
\hline Bogota & 38 & $-0.250 \pm 0.091$ & $-3.4 \pm 1.2$ \\
\hline Boston & 108 & $-0.828 \pm 0.281$ & $-9.0 \pm 3.0$ \\
\hline Buenos Aires & 113 & $0.249 \pm 0.107$ & $3.1 \pm 1.3$ \\
\hline Cairo & 116 & $0.414 \pm 0.067$ & $5.0 \pm 0.8$ \\
\hline Chengdu & 73 & $1.248 \pm 0.221$ & $8.0 \pm 1.4$ \\
\hline Chicago & 113 & $-0.684 \pm 0.191$ & $-5.1 \pm 1.4$ \\
\hline Chongqing & 67 & $1.529 \pm 0.290$ & $10.2 \pm 1.9$ \\
\hline Damascus & 115 & $0.185 \pm 0.089$ & $3.1 \pm 1.5$ \\
\hline Delhi & 112 & $0.125 \pm 0.110$ & $1.4 \pm 1.2$ \\
\hline Dhaka & 107 & $0.525 \pm 0.063$ & $10.3 \pm 1.2$ \\
\hline Guangzhou & 91 & $-0.252 \pm 0.417$ & $-0.8 \pm 1.4$ \\
\hline Ho Chi Minh City & 108 & $0.049 \pm 0.044$ & $1.4 \pm 1.3$ \\
\hline Hong Kong & 105 & $-0.424 \pm 0.282$ & $-2.5 \pm 1.7$ \\
\hline Houston & 107 & $-0.540 \pm 0.157$ & $-5.4 \pm 1.6$ \\
\hline Hyderabad & 109 & $0.142 \pm 0.056$ & $4.7 \pm 1.9$ \\
\hline Istanbul & 108 & $-0.047 \pm 0.230$ & $-0.4 \pm 1.9$ \\
\hline Jakarta & 108 & $-0.241 \pm 0.150$ & $-2.1 \pm 1.3$ \\
\hline Jeddah & 115 & $0.102 \pm 0.086$ & $1.6 \pm 1.3$ \\
\hline Johannesburg & 111 & $-0.488 \pm 0.193$ & $-3.1 \pm 1.2$ \\
\hline Kabul & 110 & $0.299 \pm 0.046$ & $14.3 \pm 2.2$ \\
\hline Karachi & 113 & $0.194 \pm 0.064$ & $4.0 \pm 1.3$ \\
\hline Khartoum & 116 & $0.018 \pm 0.035$ & $1.5 \pm 2.9$ \\
\hline Kinshasa & 80 & $0.036 \pm 0.035$ & $1.5 \pm 1.4$ \\
\hline Kolkata & 109 & $0.114 \pm 0.063$ & $2.6 \pm 1.4$ \\
\hline Lagos & 83 & $0.265 \pm 0.050$ & $7.8 \pm 1.5$ \\
\hline Lahore & 113 & $0.334 \pm 0.087$ & $6.0 \pm 1.6$ \\
\hline Lima & 75 & $0.363 \pm 0.108$ & $6.9 \pm 2.0$ \\
\hline London & 107 & $-0.255 \pm 0.205$ & $-1.7 \pm 1.4$ \\
\hline Los Angeles & 113 & $-1.656 \pm 0.308$ & $-5.8 \pm 1.1$ \\
\hline Madras & 106 & $0.151 \pm 0.058$ & $3.9 \pm 1.5$ \\
\hline Manila & 102 & $-0.363 \pm 0.074$ & $-6.0 \pm 1.2$ \\
\hline Melbourne & 111 & $-0.103 \pm 0.082$ & $-1.6 \pm 1.3$ \\
\hline Mexico City & 104 & $-0.354 \pm 0.276$ & $-1.3 \pm 1.0$ \\
\hline Moscow & 95 & $-0.185 \pm 0.273$ & $-1.2 \pm 1.8$ \\
\hline Mumbai & 103 & $0.037 \pm 0.077$ & $0.6 \pm 1.2$ \\
\hline Nagoya & 101 & $-0.400 \pm 0.244$ & $-2.3 \pm 1.4$ \\
\hline Nairobi & 88 & $0.172 \pm 0.040$ & $13.1 \pm 3.0$ \\
\hline New York & 113 & $-0.950 \pm 0.310$ & $-4.3 \pm 1.4$ \\
\hline Osaka & 110 & $-0.445 \pm 0.231$ & $-2.7 \pm 1.4$ \\
\hline Paris & 108 & $-0.471 \pm 0.171$ & $-3.3 \pm 1.2$ \\
\hline Philadelphia & 109 & $-0.917 \pm 0.205$ & $-5.9 \pm 1.3$ \\
\hline Po Valley & 112 & $-0.621 \pm 0.214$ & $-3.4 \pm 1.2$ \\
\hline Rhein-Ruhr & 104 & $-0.452 \pm 0.219$ & $-2.8 \pm 1.4$ \\
\hline Rio de Janeiro & 102 & $-0.073 \pm 0.090$ & $-0.9 \pm 1.1$ \\
\hline Riyadh & 115 & $0.270 \pm 0.133$ & $2.1 \pm 1.1$ \\
\hline San Francisco & 113 & $-0.442 \pm 0.124$ & $-5.0 \pm 1.4$ \\
\hline Santiago & 115 & $0.270 \pm 0.106$ & $2.8 \pm 1.1$ \\
\hline Sao Paulo & 104 & $-0.006 \pm 0.161$ & $0.0 \pm 1.0$ \\
\hline Seoul & 105 & $-0.576 \pm 0.517$ & $-1.9 \pm 1.7$ \\
\hline Shanghai & 106 & $1.306 \pm 0.347$ & $4.2 \pm 1.1$ \\
\hline Shenyang & 106 & $1.705 \pm 0.278$ & $9.4 \pm 1.5$ \\
\hline Shenzhen & 101 & $-0.842 \pm 0.351$ & $-3.8 \pm 1.6$ \\
\hline Sydney & 111 & $-0.239 \pm 0.116$ & $-2.9 \pm 1.4$ \\
\hline Taipei & 96 & $0.040 \pm 0.209$ & $0.4 \pm 2.1$ \\
\hline Tehran & 115 & $0.634 \pm 0.216$ & $3.2 \pm 1.1$ \\
\hline Tianjin & 110 & $2.831 \pm 0.480$ & $7.7 \pm 1.3$ \\
\hline Tokyo & 108 & $-1.282 \pm 0.306$ & $-4.9 \pm 1.2$ \\
\hline Washington & 112 & $-0.740 \pm 0.184$ & $-6.3 \pm 1.6$ \\
\hline Wuhan & 107 & $1.063 \pm 0.188$ & $6.4 \pm 1.1$ \\
\hline
\end{tabular}

ations show a particularly strong decrease in $\mathrm{NO}_{2}$ after 2005 , continuing until the end of the study period. This is likely related to emission reduction measures which have been carried out during this period. In European agglomerations the $\mathrm{NO}_{2}$ decrease appears to have stopped after 2008. The South Asia region shows the clearest increasing signal as the urban agglomerations located in this area all exhibit positive trends. The averaged time series for East Asia and South America do not show a clear signal because the regions contain agglomerations with both increasing and decreasing $\mathrm{NO}_{2}$ levels.

\subsection{Impact of time series extraction methodology}

The methodology by which the time series are extracted from the satellite data can to some extent affect the magnitude of the trends, depending on the spatial homogeneity of the trends patterns in the area surrounding each urban agglomeration. In order to study this, time series were extracted from the satellite data using two approaches. The first one only used the grid cell in which the center of the urban agglomeration was located. The second approach used the average value of a $3 \times 3$ grid cell array centered on the same location.

Figure 7 illustrates the effect of the size of the averaging region on the resulting absolute and relative trends when the time series are extracted either from a single grid cell (here denoted as $\omega_{\mathrm{abs}(1 \times 1)}$ and $\left.\omega_{\text {rel }(1 \times 1)}\right)$, or as the average of a $3 \times$ 3 grid cell array centered over the study site (here denoted as $\omega_{\mathrm{abs}(3 \times 3)}$ and $\left.\omega_{\mathrm{rel}(3 \times 3)}\right)$.

The mean difference between the absolute trends, calculated as $\omega_{\mathrm{abs}(1 \times 1)}-\omega_{\mathrm{abs}(3 \times 3)}$, from time series derived from a single grid vs. a $3 \times 3$ grid cell array was found to be $0.013 \times 10^{15}$ molecules $\mathrm{cm}^{-2} \mathrm{yr}^{-1}$ with a standard deviation of $0.16 \times 10^{15}$ molecules $\mathrm{cm}^{-2} \mathrm{yr}^{-1}$ and a root mean squared error (RMSE) of $0.16 \times 10^{15}$ molecules $\mathrm{cm}^{-2} \mathrm{yr}^{-1}$. The largest deviation in absolute trends was found for Chengdu, China, with a difference of $0.5 \times 10^{15}$ molecules $\mathrm{cm}^{-2} \mathrm{yr}^{-1}$. This is likely related to the specific orography of the region around Chengdu with high mountains surrounding the city to the south, west, and north. As for deviations in relative trends, calculated as $\omega_{\text {rel }(1 \times 1)}-\omega_{\text {rel }(3 \times 3)}$, the mean difference was found to be $0.25 \% \mathrm{yr}^{-1}$ with a standard deviation of $1.09 \% \mathrm{yr}^{-1}$ and an RMSE of $1.1 \% \mathrm{yr}^{-1}$. The largest deviation in terms of relative trends was observed for the city of Lagos, Nigeria, with a value of $4.18 \% \mathrm{yr}^{-1}$.

The results above indicate that the two approaches are quite comparable and mostly differ by values that are negligible as compared to the overall magnitude of the trends and their estimated uncertainties. However, for a few cases, such as for example the city of Lagos, the trend difference between the two extraction approaches reaches values that exceed $50 \%$ of the actual trend value and thus can have a significant impact on the results. Obviously, the differences observed here are to a large extent due to variability in the spatial extent of the urban agglomerations and not in all cases a $3 \times 3$ grid cell average is warranted. Since columns rather 


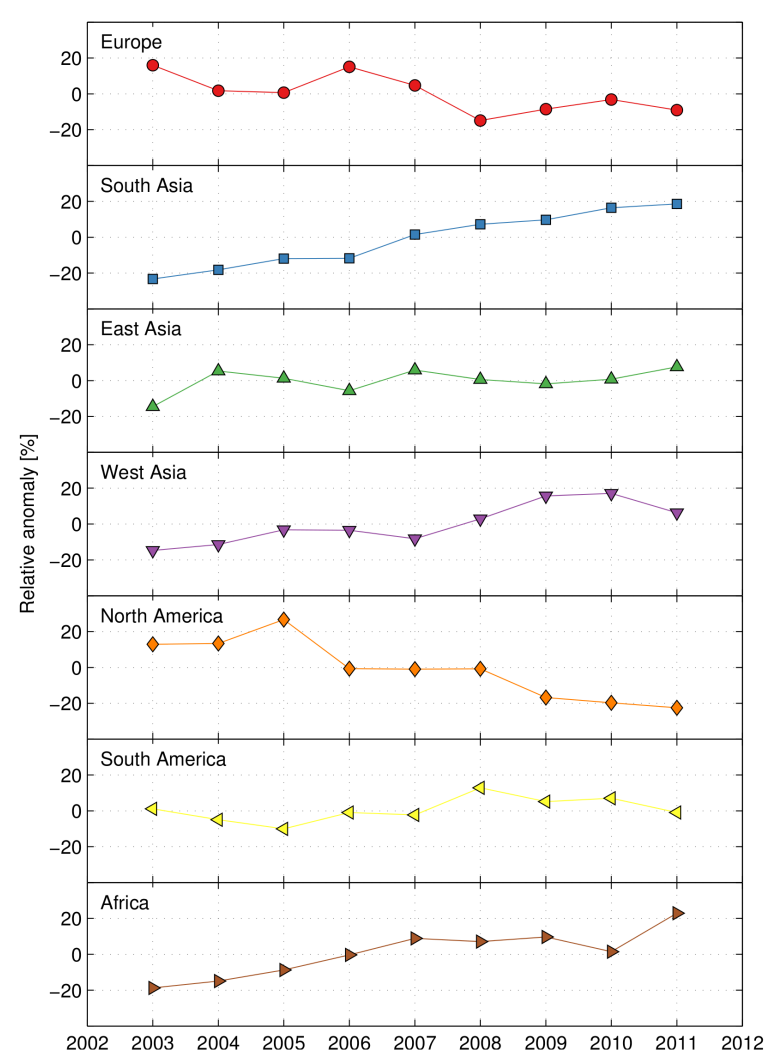

Figure 6. Interannual variability of $\mathrm{NO}_{2}$ over large urban agglomerations, averaged by region. To facilitate an easier comparison between regions, the plot shows the average of the relative anomaly (given in \%) of each sites' time series within a given region. The anomalies were computed relative to the long-term mean absolute $\mathrm{NO}_{2}$ concentration at each site.

than emissions are studied here, the spatial patterns over a $\mathrm{NO}_{\mathrm{x}}$ source such as a megacity will mostly appear spatially smoothed, which limits the effect of spatial gradients. As such, the spatial variability and the area over which the trends are computed will generally only play a significant role for agglomerations with a very large spatial extent as for example the greater Los Angeles area, which covers substantially more than 9 grid cells of the 0.25 degree $\times 0.25$ degree spatial resolution $\mathrm{NO}_{2}$ product used here.

Therefore, while the $3 \times 3$ grid cell array approach has the advantage of providing more valid monthly mean values and thus time series which result in a slightly better model fit, it was decided here to use the single grid cell approach for extracting the time series as it ensures that all sites are well represented in the time series, independent of the spatial shape and size of the city. For agglomerations with a very large spatial extent, such as Los Angeles, future work could explore the option of calculating the trends over the entire area covered by each site, for example as given by polygon outlines.

\section{4 $\mathrm{NO}_{2}$ trends and population growth}

$\mathrm{NO}_{2}$ concentrations are generally closely linked to population density (Lamsal et al., 2013). For this reason, the worldwide trends in tropospheric $\mathrm{NO}_{2}$ columns obtained from SCIAMACHY for the studied large urban agglomerations were compared with data on population growth at the same sites.

Figure 8 shows the relationship between population growth for the period 2000 to 2010 and satellite-derived trends in tropospheric $\mathrm{NO}_{2}$ for the period 2002 to 2012, classified by region. The results show surprisingly different behavior for each region. A linear relationship between $\mathrm{NO}_{2}$ trend and population growth can be seen for large urban agglomerations in Europe and South Asia.

In Europe the relationship roughly follows the regression equation $\omega_{\text {rel }}=-3.8+1.6 \cdot \mathrm{PG}$, where $\omega_{\text {rel }}$ is the SCIAMACHY-derived relative trend in tropospheric $\mathrm{NO}_{2}$ concentration in $\% \mathrm{yr}^{-1}$ and $\mathrm{PG}$ is the population growth over the 2000 through 2010 period given in \%. This relationship has a coefficient of determination of $R^{2}=0.74$.

Similarly, in South Asia the relationship roughly follows the regression equation $\omega_{\text {rel }}=-1.7+2.1 \cdot P G$ with an $R^{2}$ value of 0.72 . It should be noted, however, that both relationships are based on a relatively small sample size of $N=7$ and $N=10$ for Europe and South Asia, respectively.

In other regions besides Europe and South Asia, no obvious linear relationships are visible in Fig. 8, although distinct patterns do emerge. For East Asia, a clear division between Chinese and primarily Japanese/Korean agglomerations (with the exception of Hong Kong) is visible, with the former exhibiting both strong population growth and rapid increases in tropospheric $\mathrm{NO}_{2}$, whereas the latter show very weak population growth (or even loss) and decreases in tropospheric $\mathrm{NO}_{2}$ between 0 and $-5 \% \mathrm{yr}^{-1}$. A special case are the two Chinese megacities of Guangzhou and Shenzhen which, despite having strong population growth, exhibit decreasing levels of $\mathrm{NO}_{2}$, most likely due to emission reductions linked to changes in local legislation.

Only five sites were available in West Asia and no clear pattern or relationship can be inferred. Baghdad has a surprisingly rapid increase in tropospheric $\mathrm{NO}_{2}$ levels of $9 \% \mathrm{yr}^{-1}$ given its relatively low population growth of only around $1 \%$.

Megacities and large urban agglomerations in North and South America clearly fall into one of two main clusters. North American agglomerations exhibit moderate population growth between 0 and $4 \%$ for the 2000 to 2010 period, however they all show $\mathrm{NO}_{2}$ decreases between -5 and $-10 \% \mathrm{yr}^{-1}$. The exception here is Mexico City, which only exhibits very minor $\mathrm{NO}_{2}$ decreases. The other cluster is formed by South American agglomerations which exhibit mostly similar rates of population growth but, with the exception of Bogota, show constant or increasing tropospheric $\mathrm{NO}_{2}$ levels. 

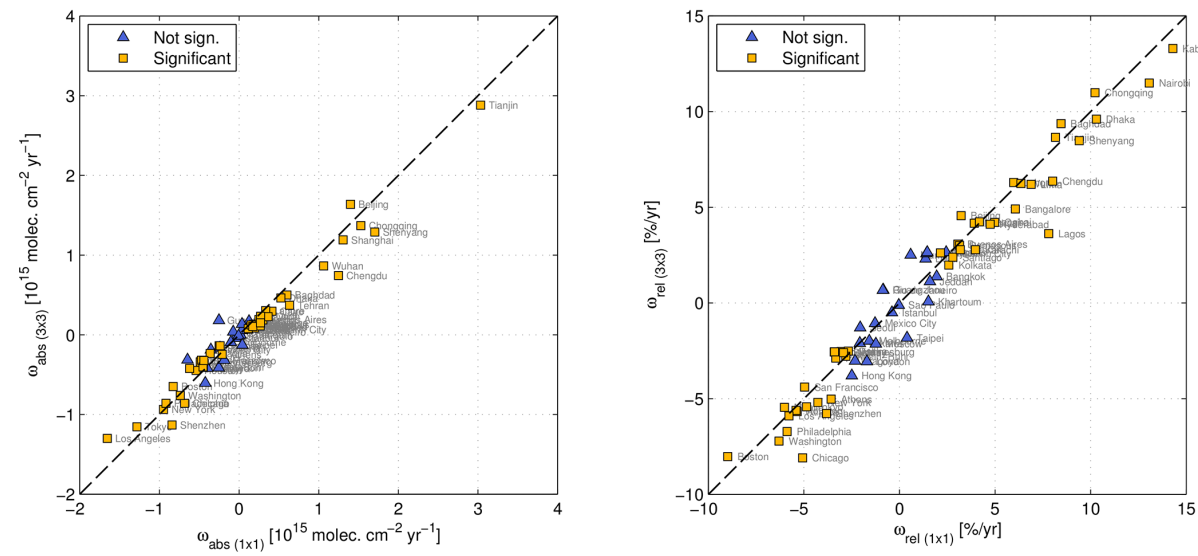

Figure 7. Comparison of absolute (left panel) and relative (right panel) trends calculated using time series extracted from a single SCIAMACHY grid cell $\left(\omega_{\mathrm{abs}(1 \times 1)}\right.$ and $\left.\omega_{\mathrm{rel}(1 \times 1)}\right)$ and as the average of an array of $3 \times 3$ SCIAMACHY grid cells $\left(\omega_{\mathrm{abs}}(3 \times 3)\right.$ and $\left.\omega_{\text {rel }(3 \times 3)}\right)$. The markers are further distinguished into trends that are statistically significant at the $p<0.05$ level (blue triangles) and those that are not (yellow squares).
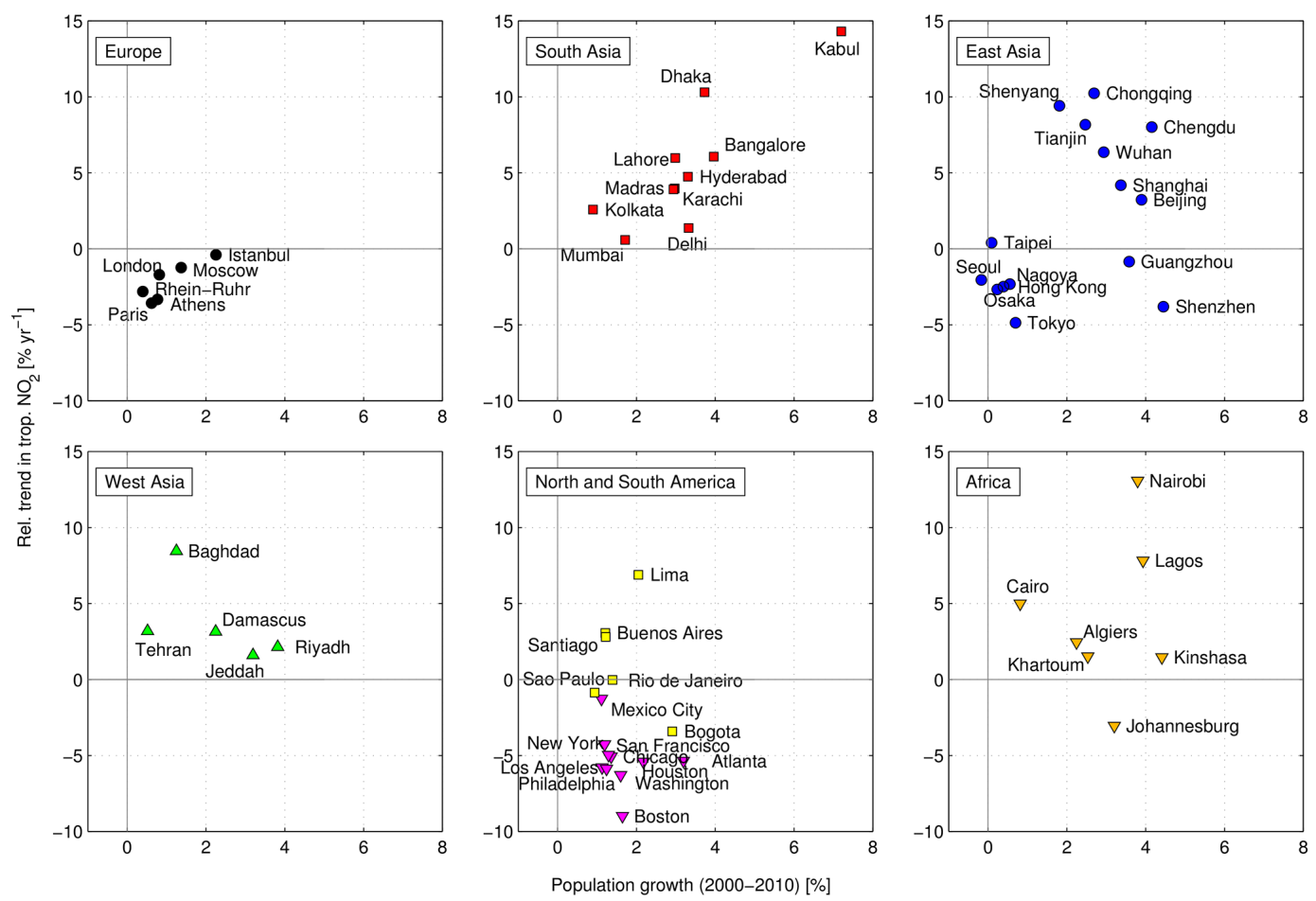

Figure 8. Relationship between population growth for the period 2000 and 2010 and SCIAMACHY-derived trends in tropospheric $\mathrm{NO}_{2}$ for 2002 to 2012, by region. North and South America were combined into a single panel, where data points in North America are shown as pink triangles and data points in South America are shown as yellow squares.

Finally, African megacities and agglomerations do not indicate a strong relationship between population growth and $\mathrm{NO}_{2}$ trend or other patterns. With most sites except Cairo exhibiting population growth rates greater than $2 \%$ for 2000 2010, Johannesburg is the only African site with decreasing tropospheric $\mathrm{NO}_{2}$ levels. All other sites exhibit growth in the tropospheric $\mathrm{NO}_{2}$ columns, which in the case of Nairobi reach very high levels of over $13 \% \mathrm{yr}^{-1}$.

These results complement a recent study by Lamsal et al. (2013) who investigated the relationship between urban surface concentrations of $\mathrm{NO}_{2}$, which were estimated from satellite and model data, and population density. They found significant correlations between these two parameters for a 
power law scaling function. The relationship was significant for all studied regions with approximately similar correlation strengths, however the slope of the power law regression varied between the regions and for China in particular. Our approach differs from that of Lamsal et al. (2013) in several aspects. Most importantly we study changes in $\mathrm{NO}_{2}$ over time and do not compare these with population density but with the change in overall population during the study period. As such, our study focuses more on investigating to what extent population changes in urban agglomerations are mirrored by changes in tropospheric $\mathrm{NO}_{2}$ levels.

It is not entirely obvious what causes the various patterns in the different regions shown in Fig. 8. Both Europe and South Asia show linear relationships as one might initially expect, with population growth explaining more rapidly increasing (or less rapidly decreasing) levels in tropospheric $\mathrm{NO}_{2}$ columns. However, the other areas do not show such a straightforward relationship and rather appear to reflect regional differences in industrial and demographic development. In some regions, for example for the agglomerations in China and West Asia, Fig. 8 even appears to indicate a weak inverse relationship, i.e., lower trends in $\mathrm{NO}_{2}$ columns with increasing population growth. This is somewhat counterintuitive but could to some extent reflect the fact that more developed and industrialized agglomerations, which already might have some legislative emission control strategies in place and thus exhibit only weakly increasing $\mathrm{NO}_{2}$ levels, could be more appealing to rural migrant workers due to better employment opportunities, thus explaining the higher population growth. Given the very low sample sizes for the individual regions with $N<10$ in most cases and the resulting uncertainty in trend patterns, however, this is mostly speculation and any interpretation going beyond this discussion is challenging. Additional research on this issue, possibly using a significantly increased number of study sites and a more detailed and targeted analysis will be necessary to better understand the underlying causes for the observed patterns.

\section{Conclusions}

Megacities and other large urban agglomerations are major hotspots for air pollution. Given the substantial global population growth and the strong tendency towards urbanization, this problem will be exacerbated in future decades. Here we present an overview of recent changes and trends in satellitederived tropospheric $\mathrm{NO}_{2}$ columns over 66 of the largest urban agglomerations worldwide. The trends were derived by fitting a statistical model including a linear trend and a seasonal component to time series extracted from the full SCIAMACHY satellite data archive for the period August 2002 to March 2012.

Overall, 44 of the 66 study sites showed statistically significant trends (either positive or negative) at the $95 \%$ level. In total, 34 sites exhibited increasing levels of tropospheric $\mathrm{NO}_{2}$ throughout the study period, 24 of which were found to be statistically significant. In addition, 32 sites showed decreasing levels of tropospheric $\mathrm{NO}_{2}$ during the study period, of which 20 sites did so at statistically significant magnitudes. The most extreme increasing absolute and relative values in trends during the study period were found for two Asian sites (Tianjin in China and Kabul in Afghanistan, respectively), whereas the most rapidly decreasing absolute and relative trends were observed for two sites in North America (Los Angeles and Boston, respectively).

Spatial patterns in worldwide trends for megacities and large urban agglomerations were studied. Similarly to previous studies investigating global tropospheric $\mathrm{NO}_{2}$ trends (van der A et al., 2008; Schneider and van der A, 2012; Hilboll et al., 2013), the characteristic patterns for trends over urban agglomerations include a spatially homogeneous reduction in tropospheric $\mathrm{NO}_{2}$ columns over both Europe and North America of around $-5 \% \mathrm{yr}^{-1}$, and moderately to rapidly increasing tropospheric column amounts of $\mathrm{NO}_{2}$ over large parts of Asia as well as Africa and South America, reaching relative trend magnitudes as high as $15 \% \mathrm{yr}^{-1}$.

In addition to spatial patterns, the time series over the urban agglomerations were studied both at the global and regional level. At the global level no strong overall trends were observed, but a signal of the 2008/2009 economical crisis was identified. The analysis of average time series at the regional level confirmed the overall patterns found in the spatial analysis. Finally, the relationship between the satellitederived $\mathrm{NO}_{2}$ trends over urban agglomerations and urban population growth was investigated. Clear linear relationships were found for Europe and South Asia, but other regions did not indicate such relationships, although characteristic clusters distinguishing sites in developing vs. developed countries did emerge.

Overall, this study provides what is currently the most comprehensive global overview of recent changes in tropospheric $\mathrm{NO}_{2}$ levels over large urban agglomerations worldwide. It was carried out using a homogeneous and consistent satellite data set acquired from a single instrument and processed using a single algorithm, thus providing trends with a high accuracy and free of inter-sensor calibration issues. Trend analysis is one of the most useful applications of satellite data of atmospheric composition and future satellite instruments, for example those to be launched within the framework of the European Copernicus Programme, will continue the $\mathrm{NO}_{2}$ record provided by SCIAMACHY and other satellite instruments. As such the study of $\mathrm{NO}_{2}$ trends from predecessor satellite instruments is very relevant for users of $\mathrm{NO}_{2}$ data from the future Copernicus satellites, both in terms of extending the $\mathrm{NO}_{2}$ trends and for assessing the quality of $\mathrm{NO}_{2}$ data from these future satellites.

An important next step with respect to monitoring changes in tropospheric $\mathrm{NO}_{2}$ from space will be the direct validation of satellite-derived trends. There are now several stations worldwide providing observations from ground-based MAX- 
DOAS instruments (Hönninger et al., 2004; Irie et al., 2012; Kanaya et al., 2014; Hendrick et al., 2014), providing highly accurate measurements of tropospheric columns of various trace gases. Some of these stations now provide time series of $5 \mathrm{yr}$ and more, thus allowing for a direct comparison of satellite-derived trends with trends obtained from a reliable reference source. Such a direct validation will add value to $\mathrm{NO}_{2}$ trends computed from the various satellite products as it will provide a realistic estimate of the uncertainty involved in such analyses.

Acknowledgements. This work has been partially supported by the MACC-II project funded by the European Union under the Seventh Framework Programme (FP7 THEME [SPA.2011.1.5-02]) under grant agreement n. 283576. Further funding was provided by the Norwegian Space Centre within the SatMonAir-I and SatMonAir-II projects. We gratefully acknowledge the free use of tropospheric $\mathrm{NO}_{2}$ column data from the SCIAMACHY sensor provided by www.temis.nl.

Edited by: R. Engelen

\section{References}

Baklanov, A., Lawrence, M., Pandis, S., Mahura, A., Finardi, S., Moussiopoulos, N., Beekmann, M., Laj, P., Gomes, L., Jaffrezo, J.-L., Borbon, A., Coll, I., Gros, V., Sciare, J., Kukkonen, J., Galmarini, S., Giorgi, F., Grimmond, S., Esau, I., Stohl, A., Denby, B., Wagner, T., Butler, T., Baltensperger, U., Builtjes, P., van den Hout, D., van der Gon, H. D., Collins, B., Schluenzen, H., Kulmala, M., Zilitinkevich, S., Sokhi, R., Friedrich, R., Theloke, J., Kummer, U., Jalkinen, L., Halenka, T., Wiedensholer, A., Pyle, J., and Rossow, W. B.: MEGAPOLI: concept of multi-scale modelling of megacity impact on air quality and climate, Adv. Sci. Res., 4, 115-120, doi:10.5194/asr-4115-2010, 2010.

Blond, N., Boersma, K. F., Eskes, H. J., van der A, R. J., Van Roozendael, M., De Smedt, I., Bergametti, G., and Vautard, R.: Intercomparison of SCIAMACHY nitrogen dioxide observations, in situ measurements and air quality modeling results over Western Europe, J. Geophys. Res., 112, 1-20, doi:10.1029/2006JD007277, 2007.

Boersma, K. F., Eskes, H. F., and Brinksma, E. J.: Error analysis for tropospheric $\mathrm{NO}_{2}$ retrieval from space, J. Geophys. Res., 109, D04311, doi:10.1029/2003JD003962, 2004.

Boersma, K. F., Eskes, H. J., Veefkind, J. P., Brinksma, E. J., van der A, R. J., Sneep, M., van den Oord, G. H. J., Levelt, P. F., Stammes, P., Gleason, J. F., and Bucsela, E. J.: Near-real time retrieval of tropospheric $\mathrm{NO}_{2}$ from OMI, Atmos. Chem. Phys., 7, 2103-2118, doi:10.5194/acp-7-2103-2007, 2007.

Boersma, K. F., Jacob, D. J., Trainic, M., Rudich, Y., DeSmedt, I., Dirksen, R., and Eskes, H. J.: Validation of urban $\mathrm{NO}_{2}$ concentrations and their diurnal and seasonal variations observed from the SCIAMACHY and OMI sensors using in situ surface measurements in Israeli cities, Atmos. Chem. Phys., 9, 3867-3879, doi:10.5194/acp-9-3867-2009, 2009.
Boersma, K. F., Eskes, H. J., Dirksen, R. J., van der A, R. J., Veefkind, J. P., Stammes, P., Huijnen, V., Kleipool, Q. L., Sneep, M., Claas, J., Leitão, J., Richter, A., Zhou, Y., and Brunner, D.: An improved tropospheric $\mathrm{NO}_{2}$ column retrieval algorithm for the Ozone Monitoring Instrument, Atmos. Meas. Tech., 4, 1905-1928, doi:10.5194/amt-4-1905-2011, 2011.

Bovensmann, H., Burrows, J. P., Buchwitz, M., Frerick, J., Noël, S., Rozanov, V. V., Chance, K. V., and Goede, A. P. H.: SCIAMACHY: Mission Objectives and Measurement Modes, J. Atmos. Sci., 56, 127-150, doi:10.1175/15200469(1999)056<0127:SMOAMM>2.0.CO;2, 1999.

Burrows, J. P., Platt, U., and Borrell, P., eds.: The Remote Sensing of Tropospheric Composition from Space, Springer, 2011.

Callies, J., Corpaccioli, E., Eisinger, M., Hahne, A., and Lefebvre, A.: GOME-2 - Metop's Second-Generation Sensor for Operational Ozone Monitoring, ESA Bulletin, 102, 28-36, 2000.

Cassiani, M., Stohl, A., and Eckhardt, S.: The dispersion characteristics of air pollution from the world's megacities, Atmos. Chem. Phys., 13, 9975-9996, doi:10.5194/acp-13-9975-2013, 2013.

Castellanos, P. and Boersma, K. F.: Reductions in nitrogen oxides over Europe driven by environmental policy and economic recession, Scientific Reports, 2, 265, doi:10.1038/srep00265, 2012.

Chan, C. K. and Yao, X.: Air pollution in mega cities in China, Atmos. Environ., 42, 1-42, doi:10.1016/j.atmosenv.2007.09.003, 2008.

Curier, R. L., Kranenburg, R., Segers, A. J. S., Timmermans, R. M. A., and Schaap, M.: Synergistic use of $\mathrm{OMI} \mathrm{NO}_{2}$ tropospheric columns and LOTOS-EUROS to evaluate the $\mathrm{NO}_{\mathrm{x}}$ emission trends across Europe, Remote Sensing of Environment, 149, 58-69, doi:10.1016/j.rse.2014.03.032, http://dx.doi.org/10.1016/ j.rse.2014.03.032, 2014.

Constantin, D.-E., Voiculescu, M., and Georgescu, L.: Satellite observations of $\mathrm{NO}_{2}$ trend over Romania., The Scientific World Journal, 1-10, doi:10.1155/2013/261634, 2013.

De Ruyter de Wildt, M., Eskes, H., and Boersma, K. F.: The global economic cycle and satellite-derived $\mathrm{NO}_{2}$ trends over shipping lanes, Geophys. Res. Lett., 39, 2-7, doi:10.1029/2011GL049541, 2012.

Dentener, F., van Weele, M., Krol, M., Houweling, S., and van Velthoven, P.: Trends and inter-annual variability of methane emissions derived from 1979-1993 global CTM simulations, Atmos. Chem. Phys., 3, 73-88, doi:10.5194/acp-3-73-2003, 2003.

Dirksen, R. J., Boersma, K. F., Eskes, H. J., Ionov, D. V., Bucsela, E. J., Levelt, P. F., and Kelder, H. M.: Evaluation of stratospheric $\mathrm{NO}_{2}$ retrieved from the Ozone Monitoring Instrument: Intercomparison, diurnal cycle, and trending, J. Geophys. Res., 116, D08305, doi:10.1029/2010JD014943, 2011.

Duncan, B. N., Prados, A. I., Lamsal, L. N., Liu, Y., Streets, D. G., Gupta, P., Hilsenrath, E., Kahn, R. A., Nielsen, J. E., Beyersdorf, A. J., Burton, S. P., Fiore, A. M., Fishman, J., Henze, D. K., Hostetler, C. A., Krotkov, N. A., Lee, P., Lin, M., Pawson, S., Pfister, G., Pickering, K. E., Pierce, R. B., Yoshida, Y., and Ziemba, L. D.: Satellite data of atmospheric pollution for U.S. air quality applications: Examples of applications, summary of data end-user resources, answers to FAQs, and common mistakes to avoid, Atmos. Environ., 94, 647-662, doi:10.1016/j.atmosenv.2014.05.061, 2014.

Fenger, J.: Urban air quality, Atmos. Environ., 33, 4877-4900, doi:10.1016/S1352-2310(99)00290-3, 1999. 
Flemming, J., Inness, A., Flentje, H., Huijnen, V., Moinat, P., Schultz, M. G., and Stein, O.: Coupling global chemistry transport models to ECMWF's integrated forecast system, Geosci. Model Dev., 2, 253-265, doi:10.5194/gmd-2-253-2009, 2009.

Ghude, S. D., Fadnavis, S., Beig, G., Polade, S. D., and van der A, R. J.: Detection of surface emission hot spots, trends, and seasonal cycle from satellite-retrieved $\mathrm{NO}_{2}$ over India, J. Geophys. Res., 113, 1-13, doi:10.1029/2007JD009615, 2008.

Ghude, S. D., Van der A, R. J., Beig, G., Fadnavis, S., and Polade, S. D.: Satellite derived trends in $\mathrm{NO}_{2}$ over the major global hotspot regions during the past decade and their inter-comparison, Environ. Pollut., 157, 1873-1878, doi:10.1016/j.envpol.2009.01.013, 2009.

Gottwald, M., Bovensmann, H., Lichtenberg, G., Noel, S., Bargen, A. von, Slijkhuis, S., Piters, A., Hoogeveen, R., Savigny, C. von, Buchwitz, M., Kokhanovsky, A., Richter, A., Rozanov, A., Holzer-Popp, T., Bramstedt, K., Lambert, J.-C., Skupin, J., Wittrock, F., Schrijver, H., and Burrows, J. P.: SCIAMACHY - Exploring the Changing Earth's Atmosphere, Springer, Dordrecht, the Netherlands, 2011.

Guerreiro, C. B., Foltescu, V., and de Leeuw, F.: Air quality status and trends in Europe, Atmospheric Environment, 98, 376-384, doi:10.1016/j.atmosenv.2014.09.017, 2014.

Gurjar, B., Butler, T., Lawrence, M., and Lelieveld, J.: Evaluation of emissions and air quality in megacities, Atmos. Environ., 42, 1593-1606, doi:10.1016/j.atmosenv.2007.10.048, 2008.

Gurjar, B., Jain, A., Sharma, A., Agarwal, A., Gupta, P., Nagpure, A. S., and Lelieveld, J.: Human health risks in megacities due to air pollution, Atmos. Environ., 44, 4606-4613, doi:10.1016/j.atmosenv.2010.08.011, 2010.

Hayn, M., Beirle, S., Hamprecht, F. A., Platt, U., Menze, B. H., and Wagner, T.: Analysing spatio-temporal patterns of the global $\mathrm{NO}_{2}$-distribution retrieved from GOME satellite observations using a generalized additive model, Atmos. Chem. Phys., 9, 64596477, doi:10.5194/acp-9-6459-2009, 2009.

Hendrick, F., Müller, J.-F., Clémer, K., Wang, P., De Mazière, M., Fayt, C., Gielen, C., Hermans, C., Ma, J. Z., Pinardi, G., Stavrakou, T., Vlemmix, T., and Van Roozendael, M.: Four years of ground-based MAX-DOAS observations of HONO and $\mathrm{NO}_{2}$ in the Beijing area, Atmos. Chem. Phys., 14, 765-781, doi:10.5194/acp-14-765-2014, 2014.

Heue, K.-P., Richter, A., Bruns, M., Burrows, J. P., v. Friedeburg, C., Platt, U., Pundt, I., Wang, P., and Wagner, T.: Validation of SCIAMACHY tropospheric $\mathrm{NO}_{2}$-columns with AMAXDOAS measurements, Atmos. Chem. Phys., 5, 1039-1051, doi:10.5194/acp5-1039-2005, 2005.

Hilboll, A., Richter, A., and Burrows, J. P.: Long-term changes of tropospheric $\mathrm{NO}_{2}$ over megacities derived from multiple satellite instruments, Atmos. Chem. Phys., 13, 4145-4169, doi:10.5194/acp-13-4145-2013, 2013.

Hönninger, G., von Friedeburg, C., and Platt, U.: Multi axis differential optical absorption spectroscopy (MAX-DOAS), Atmos. Chem. Phys., 4, 231-254, doi:10.5194/acp-4-231-2004, 2004.

Inness, A., Baier, F., Benedetti, A., Bouarar, I., Chabrillat, S., Clark, H., Clerbaux, C., Coheur, P., Engelen, R. J., Errera, Q., Flemming, J., George, M., Granier, C., Hadji-Lazaro, J., Huijnen, V., Hurtmans, D., Jones, L., Kaiser, J. W., Kapsomenakis, J., Lefever, K., Leitão, J., Razinger, M., Richter, A., Schultz, M. G., Simmons, A. J., Suttie, M., Stein, O., Thépaut, J.-N., Thouret, V.,
Vrekoussis, M., Zerefos, C., and the MACC team: The MACC reanalysis: an 8 yr data set of atmospheric composition, Atmos. Chem. Phys., 13, 4073-4109, doi:10.5194/acp-13-4073-2013, 2013.

Ionov, D. V.: Tropospheric $\mathrm{NO}_{2}$ trend over St. Petersburg (Russia) as measured from space, Russian Journal of Earth Sciences, 11, 1-7, doi:10.2205/2010ES000437, 2010.

Irie, H., Boersma, K. F., Kanaya, Y., Takashima, H., Pan, X., and Wang, Z. F.: Quantitative bias estimates for tropospheric $\mathrm{NO}_{2}$ columns retrieved from SCIAMACHY, OMI, and GOME-2 using a common standard for East Asia, Atmos. Meas. Tech., 5, 2403-2411, doi:10.5194/amt-5-2403-2012, 2012.

Jarque, C. M. and Bera, A. K.: A test for normality of observations and regression residuals, International Statistical Review, 55, 163-172, http://www.jstor.org/stable/1403192, 1987.

Kanakidou, M., Mihalopoulos, N., Kindap, T., Im, U., Vrekoussis, M., Gerasopoulos, E., Dermitzaki, E., Unal, A., Koçak, M., Markakis, K., Melas, D., Kouvarakis, G., Youssef, A. F., Richter, A., Hatzianastassiou, N., Hilboll, A., Ebojie, F., Wittrock, F., von Savigny, C., Burrows, J. P., LadstaetterWeissenmayer, A., and Moubasher, H.: Megacities as hot spots of air pollution in the East Mediterranean, Atmos. Environ., 45, 1223-1235, doi:10.1016/j.atmosenv.2010.11.048, 2011.

Kanaya, Y., Irie, H., Takashima, H., Iwabuchi, H., Akimoto, H., Sudo, K., Gu, M., Chong, J., Kim, Y. J., Lee, H., Li, A., Si, F., Xu, J., Xie, P.-H., Liu, W.-Q., Dzhola, A., Postylyakov, O., Ivanov, V., Grechko, E., Terpugova, S., and Panchenko, M.: Long-term MAX-DOAS network observations of $\mathrm{NO}_{2}$ in Russia and Asia (MADRAS) during the period 2007-2012: instrumentation, elucidation of climatology, and comparisons with OMI satellite observations and global model simulations, Atmos. Chem. Phys., 14, 7909-7927, doi:10.5194/acp-14-79092014, 2014.

Kim, S.-W., Heckel, A., McKeen, S. A., Frost, G. J., Hsie, E.-Y., Trainer, M. K., Richter, A., Burrows, J. P., Peckham, S. E., and Grell, G. A.: Satellite-observed U. S. power plant $\mathrm{NO}_{\mathrm{x}}$ emission reductions and their impact on air quality, Geophys. Res. Lett., 33, 1-5, doi:10.1029/2006GL027749, 2006.

Konovalov, I. B., Beekmann, M., Richter, A., and Burrows, J. P.: Inverse modelling of the spatial distribution of $\mathrm{NO}_{\mathrm{x}}$ emissions on a continental scale using satellite data, Atmos. Chem. Phys., 6, 1747-1770, doi:10.5194/acp-6-1747-2006, 2006.

Konovalov, I. B., Beekmann, M., Burrows, J. P., and Richter, A.: Satellite measurement based estimates of decadal changes in European nitrogen oxides emissions, Atmos. Chem. Phys., 8, 26232641, doi:10.5194/acp-8-2623-2008, 2008.

Konovalov, I. B., Beekmann, M., Richter, A., Burrows, J. P., and Hilboll, A.: Multi-annual changes of $\mathrm{NO}_{\mathrm{x}}$ emissions in megacity regions: nonlinear trend analysis of satellite measurement based estimates, Atmos. Chem. Phys., 10, 8481-8498, doi:10.5194/acp-10-8481-2010, 2010.

Lahoz, W. A., Peuch, V.-H., Orphal, J., Attié, J.-L., Chance, K., Liu, X., Edwards, D., Elbern, H., Flaud, J.-M., Claeyman, M., and Amraoui, L. E.: Monitoring Air Quality from Space: The Case for the Geostationary Platform, Bull. Am. Meteorol. Soc., 93, 221-233, doi:10.1175/BAMS-D-11-00045.1, 2012.

Lahoz, W. A. and Schneider, P.: Data assimilation: making sense of Earth Observation, Front. Environ. Sci., 2, 1-28, doi:10.3389/fenvs.2014.00016, 2014. 
Lamsal, L. N., Martin, R. V., Parrish, D. D., and Krotkov, N. A.: Scaling relationship for $\mathrm{NO}_{2}$ pollution and urban population size: a satellite perspective, Environ. Sci. Technol., 47, 78557861, doi:10.1021/es400744g, 2013.

Levelt, P., van den Oord, G., Dobber, M., Malkki, A., Stammes, P., Lundell, J., and Saari, H.: The Ozone Monitoring Instrument, IEEE Trans. Geosci. Remote Sens., 44, 1093-1101, doi:10.1109/TGRS.2006.872333, 2006.

Liu, J. and Zhu, T.: $\mathrm{NO}_{\mathrm{x}}$ in Chinese Megacities, in: Disposal of Dangerous Chemicals in Urban Areas and Mega Cities, edited by Barnes, I. and Rudziński, K. J., in NATO Science for Peace and Security Series C: Environmental Security, pp. 249263, Springer Netherlands, Dordrecht, doi:10.1007/978-94-0075034-0, 2013.

Mage, D., Ozolins, G., Peterson, P., Webster, A., Orthofer, R., Vandeweerd, V., and Gwynne, M.: Urban air pollution in megacities of the world, Atmos. Environ., 30, 681-686, doi:10.1016/13522310(95)00219-7, 1996.

Martin, R. V.: Satellite remote sensing of surface air quality, Atmos. Environ., 42, 7823-7843, doi:10.1016/j.atmosenv.2008.07.018, 2008.

Mayer, H.: Air pollution in cities, Atmos. Environ., 33, 4029-4037, doi:10.1016/S1352-2310(99)00144-2, 1999.

Meena, G. S., Patil, S. D., Manoj, M. G., and Devara, P. C. S.: Tropospheric $\mathrm{NO}_{2}$ variability over the metropolitan cities and hill stations of India, Natural Hazards, 65, 723-737, doi:10.1007/s11069-012-0392-1, 2012.

Mieruch, S., Noël, S., Bovensmann, H., and Burrows, J. P.: Analysis of global water vapour trends from satellite measurements in the visible spectral range, Atmos. Chem. Phys., 8, 491-504, doi:10.5194/acp-8-491-2008, 2008.

Molina, L. T., Molina, M. J., Slott, R. S., Kolb, C. E., Gbor, P. K., Meng, F., Singh, R. B., Galvez, O., Sloan, J. J., Anderson, W. P., Tang, X., Hu, M., Xie, S., Shao, M., Zhu, T., Zhang, Y., Gurjar, B. R., Artaxo, P. E., Oyola, P., Gramsch, E., Hidalgo, D., and Gertler, A. W.: Air quality in selected megacities, J. Air Waste Manage., 54, 1-73, doi:10.1080/10473289.2004.10471015, 2004.

Molina, M. J. and Molina, L. T.: Megacities and atmospheric pollution, J. Air Waste Manage., 54, 644-680, doi:10.1080/10473289.2004.10470936, 2004.

Monks, P., Granier, C., Fuzzi, S., Stohl, A., Williams, M., Akimoto, H., Amann, M., Baklanov, A., Baltensperger, U., Bey, I., Blake, N., Blake, R., Carslaw, K., Cooper, O., Dentener, F., Fowler, D., Fragkou, E., Frost, G., Generoso, S., Ginoux, P., Grewe, V., Guenther, A., Hansson, H., Henne, S., Hjorth, J., Hofzumahaus, A., Huntrieser, H., Isaksen, I., Jenkin, M., Kaiser, J., Kanakidou, M., Klimont, Z., Kulmala, M., Laj, P., Lawrence, M., Lee, J., Liousse, C., Maione, M., McFiggans, G., Metzger, A., Mieville, A., Moussiopoulos, N., Orlando, J., O’Dowd, C., Palmer, P., Parrish, D., Petzold, A., Platt, U., Pöschl, U., Prévôt, A., Reeves, C., Reimann, S., Rudich, Y., Sellegri, K., Steinbrecher, R., Simpson, D., ten Brink, H., Theloke, J., van der Werf, G., Vautard, R., Vestreng, V., Vlachokostas, C., and von Glasow, R.: Atmospheric composition change - global and regional air quality, Atmos. Environ., 43, 5268-5350, doi:10.1016/j.atmosenv.2009.08.021, 2009.

Parrish, D. D., Singh, H. B., Molina, L., and Madronich, S.: Air quality progress in North American megacities: a review, Atmos.
Environ., 45, 7015-7025, doi:10.1016/j.atmosenv.2011.09.039, 2011.

Richter, A., Burrows, J. P., Nüss, H., Granier, C., and Niemeier, U.: Increase in tropospheric nitrogen dioxide over China observed from space, Nature, 437, 129-32, doi:10.1038/nature04092, 2005.

Russell, A. R., Valin, L. C., and Cohen, R. C.: Trends in $\mathrm{OMI} \mathrm{NO}_{2}$ observations over the United States: effects of emission control technology and the economic recession, Atmos. Chem. Phys., 12, 12197-12209, doi:10.5194/acp-12-12197-2012, 2012.

Santer, B., Wigley, T., Boyle, J., Gaffen, D., Hnilo, J., Nychka, D., Parker, D., and Taylor, K.: Statistical significance of trends and trend differences in layer-average atmospheric temperature time series, J. Geophys. Res., 105, 7337-7356, 2000.

Schaub, D., Brunner, D., Boersma, K. F., Keller, J., Folini, D., Buchmann, B., Berresheim, H., and Staehelin, J.: SCIAMACHY tropospheric $\mathrm{NO}_{2}$ over Switzerland: estimates of $\mathrm{NO}_{\mathrm{x}}$ lifetimes and impact of the complex Alpine topography on the retrieval, Atmos. Chem. Phys., 7, 5971-5987, doi:10.5194/acp-7-5971-2007, 2007.

Schneider, P. and van der A, R. J.: A global single-sensor analysis of 2002-2011 tropospheric nitrogen dioxide trends observed from space, J. Geophys. Res., 117, 1-17, doi:10.1029/2012JD017571, 2012.

Sitnov, S. a.: Analysis of satellite observations of the tropospheric $\mathrm{NO}_{2}$ content over the Moscow region, Izvestiya, Atmospheric and Oceanic Physics, 47, 166-185, doi:10.1134/S0001433811010129, 2011.

Tiao, G., Reinsel, G. C., Daming, X., Pedrick, J. H., Xiaodong, Z., Miller, A. J., DeLuisi, J. J., Mateer, C. L., and Wuebbles, D. J.: Effects of autocorrelation and temporal sampling schemes on estimates of trend and spatial correlation, J. Geophys. Res., 95, 20507-20517, 1990.

United Nations: World Urbanization Prospects The 2011 Revision - Highlights, Tech. rep., United Nations - Department of Economic and Social Affairs - Population Division, New York, NY, 2012a.

United Nations: World Urbanization Prospects: The 2011 Revision - CD-ROM Edition, available at: http://esa.un.org/unpd/ wpp/index.htm (last access: 2 June 2014), 2012b.

van $\operatorname{der}$ A, R. J., Peters, D. H. M. U., Eskes, H., Boersma, K. F., Van Roozendael, M., De Smedt, I., and Kelder, H. M.: Detection of the trend and seasonal variation in tropospheric $\mathrm{NO}_{2}$ over China, J. Geophys. Res., 111, 1-10, doi:10.1029/2005JD006594, 2006. van der A, R. J., Eskes, H. J., Boersma, K. F., van Noije, T. P. C., Van Roozendael, M., De Smedt, I., Peters, D. H. M. U., and Meijer, E. W.: Trends, seasonal variability and dominant $\mathrm{NO}_{\mathrm{x}}$ source derived from a ten year record of $\mathrm{NO}_{2}$ measured from space, $\mathrm{J}$. Geophys. Res., 113, 1-12, doi:10.1029/2007JD009021, 2008.

Vrekoussis, M., Richter, A., Hilboll, A., Burrows, J. P., Gerasopoulos, E., Lelieveld, J., Barrie, L., Zerefos, C., and Mihalopoulos, N.: Economic crisis detected from space: air quality observations over Athens/Greece, Geophys. Res. Lett., 40, 458-463, doi:10.1002/grl.50118, 2013.

Weatherhead, E., Reinsel, G., Tiao, G., Meng, X., Choi, D., Cheang, W., Keller, T., DeLuisi, J., Wuebbles, D., Kerr, J., and Others: Factors affecting the detection of trends: statistical considerations and applications to environmental data, J. Geophys. Res.-Atmos., 103, 17149-17161, 1998. 
World Health Organization: Review of evidence on health aspects of air pollution REVIHAAP Project, Tech. rep., Copenhagen, Denmark, 2013.

Zhou, Y., Brunner, D., Hueglin, C., Henne, S., and Staehelin, J.: Changes in OMI tropospheric $\mathrm{NO}_{2}$ columns over Europe from 2004 to 2009 and the influence of meteorological variability, Atmos. Environ., 46, 482-495, doi:10.1016/j.atmosenv.2011.09.024, 2012.
Zhu, T., Melamed, M. L., Parrish, D., Gauss, M., Gallardo Klenner, L., Lawrence, M., Konare, A., and Liousse, C.: Impacts of Megacities on Air Pollution and Climate, Tech. Rep. 205, WMO/IGAC, Geneva, Switzerland, 2012. 